Article

\title{
Towards Eradication of Phytophthora cinnamomi Using a Fallow Approach in a Mediterranean Climate ${ }^{\dagger}$
}

\author{
William A. Dunstan ${ }^{1}$, Kay Howard ${ }^{1}{ }^{\oplus}$, Andrew Grigg ${ }^{2}$, Christopher Shaw ${ }^{1}$,
} Treena I. Burgess ${ }^{1}$ (D) and Giles E. St. J. Hardy ${ }^{1, *(D)}$

1 Phytophthora Science and Management, Centre for Climate Impacted Terrestrial Ecosystems, Harry Butler Institute, Murdoch University, 90 South Street, Murdoch, WA 6150, Australia; W.Dunstan@murdoch.edu.au (W.A.D.); K.Howard@murdoch.edu.au (K.H.); c.shaw@murdoch.edu.au (C.S.); t.burgess@murdoch.edu.au (T.I.B.)

2 Alcoa of Australia, Pinjarra, WA 6208, Australia; Andrew.Grigg@alcoa.com.au

* Correspondence: g.hardy@murdoch.edu.au; Tel.: +61-8-9360-7537

$+\quad$ This paper is in memory of Dr. Ian Colquhoun (I.C.) who passed away in 2015. He was a huge advocate of Phytophthora science and management in Australia for over 25 years. He worked tirelessly with industry, universities, government and non-government agencies, and community groups. His ability to bring people together to achieve common goals aimed at the management of Phytophthora was legendary. He was a primary instigator of the research outlined in this paper, both in the research objectives and obtaining funding support. He is fondly remembered by many friends he made across Australia and world-wide.

Received: 11 September 2020; Accepted: 8 October 2020; Published: 16 October 2020

\begin{abstract}
While eradication from haul roads was achieved, more work is required to eradicate P. cinnamomi from stockpiles and bunds. We can now implement different management strategies to the construction of bunds and stockpiles to facilitate eradication. Infestation by Phytophthora cinnamomi results in large financial and management constraints to environmental managers. This pathogen was considered impossible to eradicate until recent success with treatments including host removal, herbicide and fungicide application, soil fumigation and physical root barriers. We investigated the most benign of these treatments; keeping the area devoid of living host material. In a Western Australian mine site within a Mediterranean climate, haul roads, stockpiles and roadside bunds had P. cinnamomi colonised Pinus stem plugs buried at multiple depths. Over time, we examined the effects of soil moisture and temperature in different soil conditions and types to compare the recovery of the pathogen. Results: Within 12 months, the pathogen could not be recovered from the haul roads. In the stockpiles, depth produced significantly different results. In 3 of the 4 sites, the pathogen was not recovered at $10 \mathrm{~cm}$ after 20 months. By 12 months, at $50 \mathrm{~cm}$, there was an $80 \%$ reduction in recovery, but only one stockpile had no recovery from $50 \mathrm{~cm}$, which occurred by 36 months. Bunds were up to $1.75 \mathrm{~m}$ high and had variable results for plugs buried at $30 \mathrm{~cm}$, influenced by height, the types of soils and shading. One of the smallest bunds was the only bund where the pathogen was not recoverable (by 22 months). This study provides strong support for using a fallow period to reduce or eliminate P. cinnamomi inoculum.
\end{abstract}

Keywords: soil matric potential; pathogen survival; host elimination; soil temperature; soil moisture; host removal

\section{Introduction}

Worldwide, Phytophthora cinnamomi is listed as one of the world's 100 worst invasive alien species by the IUCN [1]. Land infested by P. cinnamomi results in huge financial and management constraints 
to forestry, managers of natural ecosystems, mining and other industries such as horticulture [2]. In Australia, P. cinnamomi is the only plant pathogen listed as a key threatening process to Australia's biodiversity and is considered at least equivalent to that of the 'transformer' class of invasive plants [3]. Reduced biodiversity threatens the viability of floriculture, eco-tourism and apiculture industries, with follow on effects to some horticultural and agricultural enterprises [4,5]. This soil borne pathogen has a major impact on forestry, extractive industries, mining and other forest users through the strict implementation of hygiene and quarantine measures used to stop the spread of the pathogen, in terms of mapping, diagnostics, hygiene, quarantine and control [6]. This pathogen is threatening food security, biodiversity and the economy.

South-Western Australia is a biodiversity hotspot [7] with over $6000 \mathrm{~km}^{2}$ infested with the introduced pathogen, P. cinnamomi. Even Alcoa of Australia's nationally and internationally recognised hygiene and quarantine measures have not been able to slow or halt the spread of the pathogen during mining or restoration activities [6,8]. Their hygiene and quarantine activities include remote and on-ground mapping, diagnostics, cleaning earthmoving equipment, signage, on-going training, engineered bunds and sumps for drainage, segregation of infested and non-infested soils and overburden, and the building of 'dieback-free' roads as 'green-bridges' across infested areas. The rate of spread of disease caused by P. cinnamomi due to mining operations was estimated to be $6-70 \mathrm{~m}^{2} /$ ha/annum of forest cleared for bauxite mining [9]. It is estimated that $40 \%$ of the rich diversity of plants (5710 described species) are susceptible to P. cinnamomi [10], leaving biodiversity in the South-West Botanical under threat, as is the case in other regions of the world.

While phosphite successfully reduces $P$. cinnamomi disease incidence in treated plants, its effectiveness declines with time and requires repeated applications [11,12]. Recognising the need to move beyond control offered by phosphite or hygiene as part of integrated management, field experiments were undertaken for the containment and/or eradication of P. cinnamomi. These experiments demonstrated both outcomes were possible in two very different climatic zones, one in Tasmania and the other in South-Western Australia [13]. Treatments included host removal, herbicide application, fungicide application, soil fumigation and physical root barriers. Phytophthora cinnamomi could not be recovered from either site, to depths of $2 \mathrm{~m}$, up to 18 months after treatment. Eight years later, one of the sites was still pathogen-free (Dunstan and Hardy, unpublished data). Some elements of these experimental approaches were then applied to contain two infestations in the Fitzgerald River National Park, a World Biosphere Reserve [14], and eradicate one infestation in the Cape Arid National Park. More recently, the removal of all living host material from infested jarrah forest sites through herbicide application and the prevention of germination of plant species (including annuals) ensured that P. cinnamomi, a poor competitive saprotroph [15], was not provided with a living food source, resulting in the eradication of the pathogen from gravel after 3.5 years [16]. These studies demonstrate the potential to eradicate this pathogen.

Host removal has been successful in 55\% of eradication programs recorded in the Global Eradication and Response Database [17]. However, elimination of any soil borne pathogen is dependent on its survival ability and the environmental conditions. There have been many studies on P. cinnamomi, often based on temperature alone, and often under laboratory or glasshouse conditions (see review [18]). Burgess et al. [19] and [20] have reported field survival and ability to cause disease at temperatures $<6{ }^{\circ} \mathrm{C}$, while Gallo et al. [21] demonstrated inactivation of the pathogen in dry soils at $38^{\circ} \mathrm{C}$ after $2 \mathrm{~h}$, with $2 \mathrm{~h}$ at 40 or $42^{\circ} \mathrm{C}$ killing all propagules. However, moisture plays an important part in survival of Oomycetes. When there is low soil matric potential and low organic matter content, P. cinnamomi has been shown to only survive for 2-4 months [22]. Gyeltshen et al. [23] demonstrated that within 12 months, at least $96 \%$ of oospores lost their viability, regardless of soil moisture, and chlamydospores were no longer viable at 3 months. Where living plants were present, they found the slowest decline of pathogen viability compared to a fallow control and the use of fungicides.

To enhance our understanding of the eradication process in fallow soils, we investigated the effect of soil moisture and temperature, at different depths, in different soil conditions (haul roads, large stock 
piles of topsoil, and road-side bunds) on the survival of P. cinnamomi in the absence of living host material. The findings from this experiment will have national economic, environmental and social benefits. A reduction of areas infested with P. cinnamomi will improve the quality, biodiversity and ecosystem resilience of restored areas, and help reduce the spread of Phytophthora species through autonomous movement.

\section{Materials and Methods}

\subsection{Location}

These experiments were undertaken at Alcoa of Australia's Huntly minesite, located in the Jarrah forest of South-West Western Australia (WA), $\sim 80 \mathrm{~km}$ SE of Perth. On the Darling Scarp, this area has a Mediterranean climate with long, hot, dry summers and cool, wet winters. Sitting on lateritic upland [24], the soils are highly weathered, ancient lateritic Kandosols or Oxisols [25]. This gently undulating ancient plateau is composed of Archean granitic rocks intruded by Proterozoic dolerite dykes. Weathering has produced regolith profiles to $>50 \mathrm{~m}$ deep. There is about $0.5 \mathrm{~m}$ of sandy gravel overlying duricrust; a concretionary layer of laterite [6]. Selection of location was based on areas confirmed as P. cinnamomi infested by Alcoa's standard dieback interpretation and baiting methods prior to mining. Three types of minesite structures were assessed; haul roads, stockpiles and bunds. The experimental sites were set up at two localities, Myara and McCoy, $20 \mathrm{~km}$ apart. Within localities, the mean distance between individual experimental sites was $2.9 \mathrm{~km}$ for roads and bunds (McCoy), $3 \mathrm{~km}$ for bunds at Myara, and $5.7 \mathrm{~km}$ for stockpiles (McCoy).

\subsection{Experimental Design}

The experiment took place between April 2015 and September 2018, with three site types investigated: roads, stockpiles and road bunds. There were four sites each for roads and stockpiles, and two bund locations each with four sites. Plugs of pathogen inoculum were installed at 10 and $50 \mathrm{~cm}$ in roads and stockpiles and at $30 \mathrm{~cm}$ in the bunds. These depths were chosen as it was reported that inoculum levels were highest in these areas at $10 \mathrm{~cm}$ (topsoil) and $50 \mathrm{~cm}$ deep [26]. The recovery of the inoculum plugs to check for pathogen viability occurred between 5 and 38 months after installation with 4 harvest times for each site.

Soil moisture and temperature were measured at depths of 10, 20, 30, 40, 50, 60, 80, 100 and $120 \mathrm{~cm}$ at Silky Oak roads (Figure S1) and stockpiles between May 2015 and September 2018 (Figure S2), and between May 2015 and August 2016 at Redwood stockpiles (Figure S3). The experimental arrays and buffer zones in haul roads were free of living plant material at commencement and for the duration of the experiment.

For the bunds, five of eight sites were naturally plant free at commencement of the experiments and there was no recruitment of plants for the duration. The remaining three bund sites had some small eucalypt seedlings present, which were removed at commencement. In stockpiles, all plants were removed by hand from experimental plots and surrounding buffer zones at the start of the trial. Thereafter, sites were visited every 3 months and any seedlings were removed by hand (including roots).

\subsubsection{Roads}

The construction of unsealed haul roads through the forested areas to be mined requires topsoil removal, secondary overburden removal, both stockpiled separately. Any drilling or blasting is undertaken to remove rock, then the area is levelled by bulldozers. The road material is hauled from pits within the forest, placed and compacted. The haul roads are formed from a combination of clay, gravel and sand, and, in some instances, have crushed rock near the surface, but in WA, usually gravels. During construction of haul roads, a minimum of blasting and rock breaking is undertaken. The roads are made to a width of $22 \mathrm{~m}$, with a maximum gradient of $8-10 \%$. Depending on the requirements of 
the route, the base course is $0-150 \mathrm{~mm}$, with a sub base between 500 and $1100 \mathrm{~mm}$ deep, covered by $4 \mathrm{~m}$ of sub grade soil, and a minimum gravel surface thickness of $150 \mathrm{~mm}$.

The density of road material to $50 \mathrm{~cm}$ deep, at all sites was $2400-2800 \mathrm{~kg} / \mathrm{m}^{3}$, determined by the dry weight/volume of material from inoculation holes. Road sites (Table 1) used for the experiment were closed to all traffic from late 2014 to early 2015.

Table 1. Description of road sites used to test survival of Phytophthora cinnamomi in woody inoculum plugs at 10 and $50 \mathrm{~cm}$. Sun exposure: partial (seasonal) $=$ site shaded by adjacent vegetation for at least part of the day, mid-year.

\begin{tabular}{cccccc}
\hline Site & $\begin{array}{c}\text { Pavement } \\
\text { Orientation/Direction } \\
(\mathbf{d e g})\end{array}$ & $\begin{array}{c}\text { Average Width } \\
\mathbf{( m )}\end{array}$ & Axis Slope or Fall & Sun Exposure (Variability) & $\begin{array}{c}\text { Latitude } \\
\text { Longitude }\end{array}$ \\
\hline Silky Oak & $58 / 238$ & 22.5 & W to E & partial to full (seasonal) & $\begin{array}{c}32.536720^{\circ} \mathrm{S} \\
116.25395708^{\circ} \mathrm{E}\end{array}$ \\
\hline Yellow Tingle & $170 / 350$ & 23.5 & N to S & full & $\begin{array}{c}32.54985144^{\circ} \mathrm{S} \\
116.25486030^{\circ} \mathrm{E}\end{array}$ \\
\hline Redwood & $113 / 293$ & W to E & & full & $32.53525298^{\circ} \mathrm{S}$ \\
\hline Brigalow & $81 / 261$ & 23.8 & E to W & full & $32.52379094^{\circ} \mathrm{S}$ \\
$116.24134007^{\circ} \mathrm{E}$ \\
\hline
\end{tabular}

Although it is assumed that haul roads are free from P. cinnamomi as they were constructed with material from designated disease-free areas, it is estimated that $20-30 \%$ of haul roads traverse infested forest and bauxite was extracted from pits within infested forest, increasing the chance of pathogen presence in the roads tested.

\subsubsection{Bunds}

All major mine access roads were constructed with high bunds designed to direct surface water flow away from the forests and into sumps, with the aim of preventing infested wash from roads entering non-infested vegetation [8]. The standards of road bund construction varied between experimental sites (Table 2). The bund walls range from 1.4 to $1.75 \mathrm{~m}$ high and are made from sump spoil and crushed rock from blasted road surfaces.

Table 2. Description of bund sites used to test survival of Phytophthora cinnamomi in woody inoculum plugs at $30 \mathrm{~cm}$ which were buried on the "active face". Soil colour: from moist soil based on Munsell colour classification [27]. Soil texture, from soil fraction $\leq 2 \mathrm{~mm}$, based on classification according to Marshall [28] in McDonald et al. [29]. Sun exposure: Partial (daily) = site shaded by adjacent vegetation for part of the day; Partial (seasonal) = site shaded by adjacent vegetation for at least part of the day, mid-year.

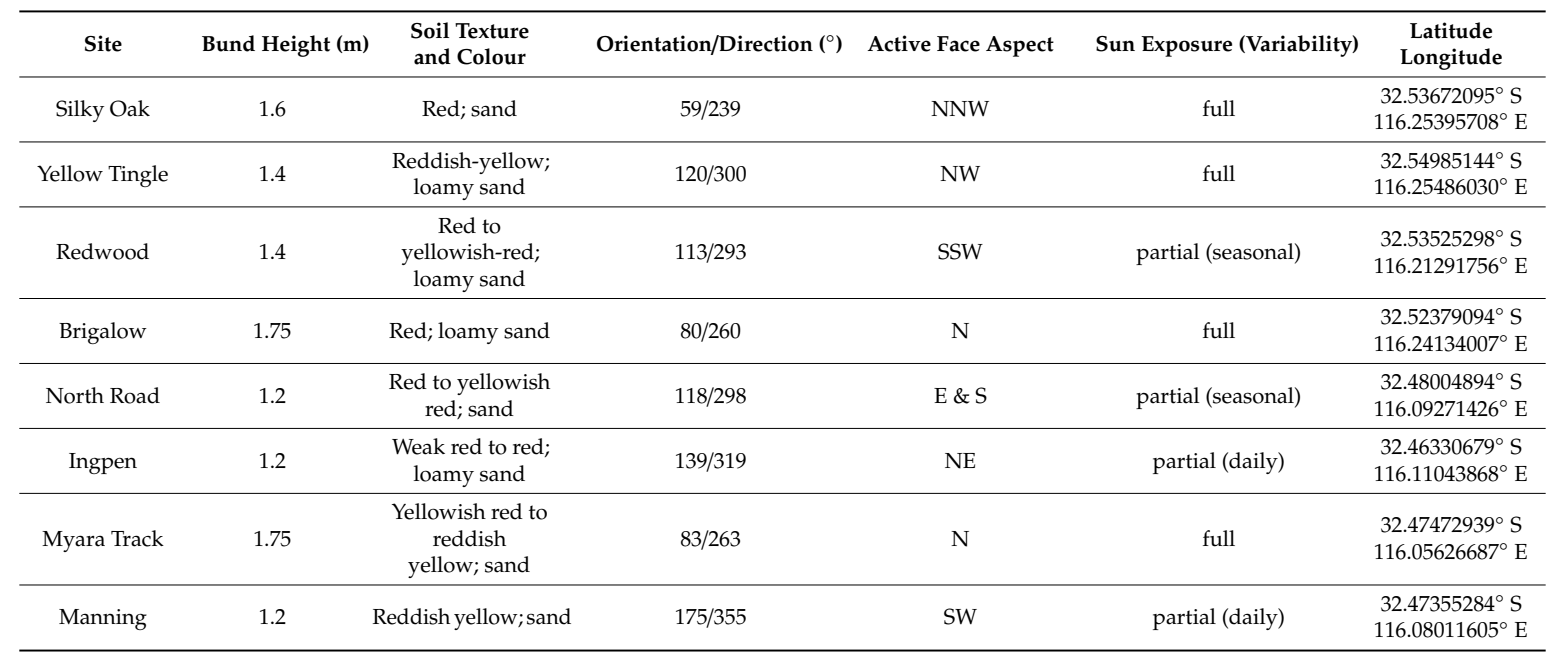




\subsubsection{Stockpiles}

Stockpiles contained topsoil and overburden (material other than topsoil overlying bauxite) that were reserved for restoration of bauxite pits post-mining (Table 3). In general, stockpiles were trapezoidal in section across the short axis and triangular to trapezoidal along the long axis, with a ramped section for vehicle access. Topsoil and overburden in the stockpiles were taken from forest infested with P. cinnamomi. When building stockpiles, the aim is to make the smallest workable pile and it is to be stored for the shortest possible time. The area where the stockpile is placed has any caprock blasted or ripped to ensure water drains vertically and not into adjacent forest areas (minimum of $4 \mathrm{~m}$ away), bunds or $\mathrm{v}$-drains may be used to direct water flow. It is graded to remove any organic matter or non-clay material and any large rocks are not put into the stockpiles. The top of the stockpile is as minimum width of $13.5 \mathrm{~m}$ and is shallower than the sides (windrows) by $0.2 \mathrm{~m}$ which are on a maximum angle of $26.5^{\circ}$. Topsoil stockpiles are generally smaller than overburden stockpiles due to the unstable nature of topsoil for stacking.

Table 3. Description of stockpile sites used to test survival of Phytophthora cinnamomi in woody inoculum plugs at 10 and $50 \mathrm{~cm}$. Sun exposure: seasonal shading = site shaded by adjacent vegetation each afternoon, mid-year.

\begin{tabular}{|c|c|c|c|c|c|c|}
\hline Site & Type & Area $\left(\mathrm{m}^{2}\right)$ & Stockpile Height (m) & Volume $\left(\mathrm{m}^{3}\right)$ & $\begin{array}{l}\text { Sun Exposure } \\
\text { (Variability) }\end{array}$ & $\begin{array}{l}\text { Latitude } \\
\text { Longitude }\end{array}$ \\
\hline Silky Oak & Overburden \& topsoil & 8300 & 6 & 24,900 & full & $\begin{array}{l}32.53569213^{\circ} \mathrm{S} \\
116.25540321^{\circ} \mathrm{E}\end{array}$ \\
\hline Yellow Tingle & Topsoil & 6300 & 7 & 22,050 & $\begin{array}{c}\text { full } \\
\text { (seasonal pm shading) }\end{array}$ & $\begin{array}{c}32.54985144^{\circ} \mathrm{S} \\
116.25486030^{\circ} \mathrm{E}\end{array}$ \\
\hline Redwood & Topsoil & 5800 & 6 & 17,400 & full & $\begin{array}{c}32.53262645^{\circ} \mathrm{S} \\
116.21123669^{\circ} \mathrm{E}\end{array}$ \\
\hline
\end{tabular}

\subsection{Soil Composition at $10 \mathrm{~cm}$}

Composite soil samples were collected from 20-25 points at each site, from depths between 0 and $50 \mathrm{~cm}$ for roads, 5 and $50 \mathrm{~cm}$ for stockpiles, and 0 to $30 \mathrm{~cm}$ for bunds. Soil was sieved $(<2 \mathrm{~mm})$ and the texture was described using McDonald et al. (1990), and soil origin was determined [24,30]. Soil analysis was undertaken by CSBP Soil and Plant Analysis Laboratory (Bibra Lake, WA, Australia) (Table S1).

The $\mathrm{pH}\left(\mathrm{CaCl}_{2}\right)$ ranged from 5.2 to 6.1 or 6.2 to $6.7\left(\mathrm{H}_{2} \mathrm{O}\right)$ across all sites (Table S1). The stockpiles had the highest average organic carbon $(1.14 \%)$ but the lowest average organic matter $(8.97 \%)$ compared to roads and bunds (Table S1). The bunds and stockpiles were most similar with average sand:silt:clay ratios of 90:6:4 and 89:8:3, respectively. Roads had a higher average component of silt with ratios of 85:14.9:0.1 (Table S1).

\subsection{Site Preparation/Vegetation Removal}

Roads and bunds are generally free of plants. At all sites, any seedlings were removed by hand at least three times per year, and any new germinants were removed by hand as they were detected. There was sparse regeneration on some stockpiles, and a plant-free buffer zone of at least $3 \mathrm{~m}$ was maintained around inoculum installation points.

\subsection{Air Temperature and Rainfall}

A climate station was installed (MAX logger, Measurement Engineering Australia, Magill, SA, Australia) at Silky Oak and Redwood to record shaded ambient air temperature at 15 min intervals, and daily rainfall using a tipping bucket gauge $(0.2 \mathrm{~mm}$ minimum recorded value). Between the two sites, there was very little difference in the daily rainfall with a maximum of $4 \mathrm{~mm}$ difference on the heaviest rainfall days and on average $<2{ }^{\circ} \mathrm{C}$ so the data for both sites were averaged (Figure 1). 
The periods of hot weather with temperatures in excess of $38^{\circ} \mathrm{C}$ (late December 2015, early February 2016, January 2017) occurred in the absence of rainfall (no rain for 7 days). The heaviest rainfall days occurred mid May 2015, mid July 2015, mid May 2016 and mid July 2016. There were two unseasonal large rainfall events in December 2016 (42 mm recorded at Redwood) and February 2017 (131 mm recorded at Silky Oak).

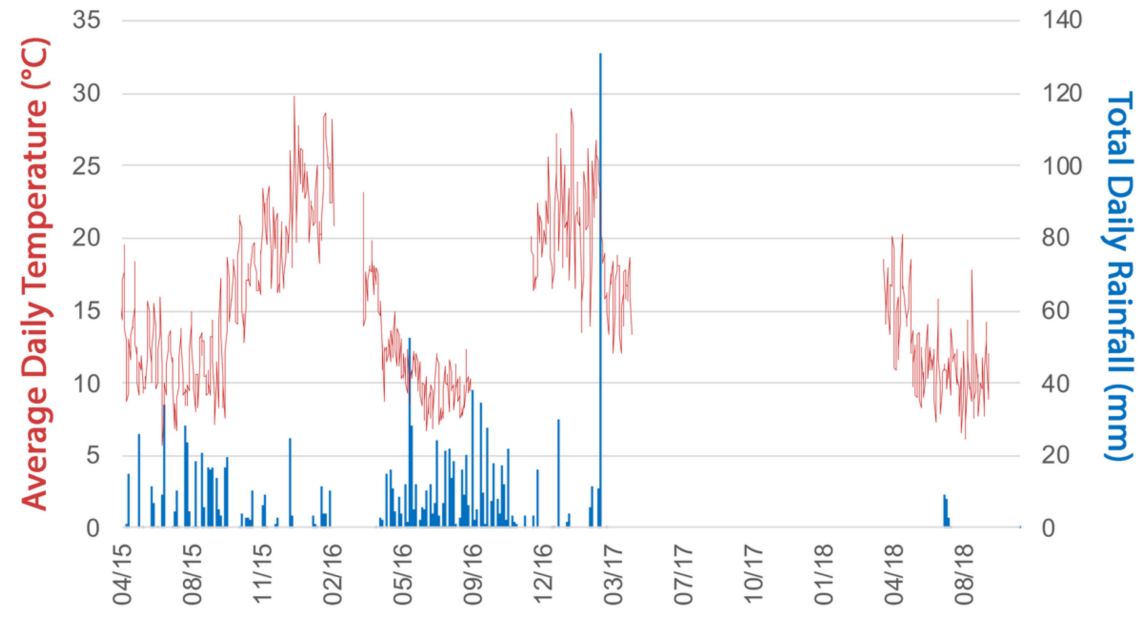

Figure 1. Average daily temperature $\left({ }^{\circ} \mathrm{C}\right)$ and rainfall $(\mathrm{mm})$ of Silky Oak and Redwood sites. Where the temperature line is discontinuous, data are missing for rainfall also, except September to November 2016.

\subsection{Inoculum Production}

Phytophthora cinnamomi (isolate MP94-48, A2 mating type) originally isolated from jarrah forest at Willowdale minesite, Western Australia ( $30 \mathrm{~km}$ south of the Huntly minesite) was used to produce inoculum. In 2 L conical flasks, 200 bark-free stem sections (plugs) of Pinus radiata (1.5-2 cm long, 8-15 mm diam.) were soaked in deionised water overnight, drained and autoclaved once $\left(121^{\circ} \mathrm{C} / 30 \mathrm{~min}\right.$; liquids cycle). Each flask of plugs was inoculated with $10 \times 1 \mathrm{~cm}^{2}$ squares of Potato Dextrose Agar (PDA, BBL, Becton, Dickinson \& Co, Sparks MD 21152 USA with 7 day-old cultures of P. cinnamomi). Flasks were incubated at $25{ }^{\circ} \mathrm{C}$ in the dark, with weekly shaking to break up mycelial mats and to ensure uniform colonisation through all the plugs. Inoculum was grown for 3 months before use. Inoculum viability was assessed by plating 10 plugs/flask onto NARH, a Phytophthora selective agar [31]. Inoculum was only used from flasks that were not contaminated and had $100 \%$ recovery of P. cinnamomi.

Inoculum plugs were enclosed in nylon mesh bags $(3 \times 5 \mathrm{~cm})$ with a locating cord attached ( $90 \mathrm{~cm}$ braided polypropylene cord or $24 \mathrm{~kg}$ breaking strain nylon line). Bags containing inoculum were stored at $18-24{ }^{\circ} \mathrm{C}$ for $<2$ days before they were installed in the field. Surplus inoculum, including samples from most flasks, not installed in the field, was retained in sealed plastic bags inside polystyrene boxes at about $14-28^{\circ} \mathrm{C}$, in the laboratory.

\subsection{Inoculum Installation}

In the road sites (Silky Oak, Yellow Tingle, Redwood and Brigalow) inoculum was installed on 10 April 2015, and at stockpiles (Silky Oak, Yellow Tingle, Redwood and Acacia) on 24 September 2015, at depths of 10 and $50 \mathrm{~cm}$. At the two areas of bunds, McCoy (Silky Oak, Yellow Tingle, Redwood and Brigalow) installation occurred on 25 June 2015, and at Myara (Manning, Myara Track, North Road and Ingpen) on 4 and 24 June 2015. Inoculum plugs were inserted to a depth of $30 \mathrm{~cm}$ in bunds, depth was limited by the internal composition of the bunds, which were mostly comprised of laterite fragments ranging in size from cobbles $(60-200 \mathrm{~mm})$ to boulders $(600 \mathrm{~mm}-2 \mathrm{~m})$. 


\subsubsection{Haul Roads}

At each road site, there were 7 arrays installed in a continuous line $(80 \mathrm{~m})$ along the axis of the road with 4 or $9.5 \mathrm{~m}$ between the arrays. Each array consisted of $5 \times 4$ holes, with $50 \mathrm{~cm}$ between hole centres, drilled to $50 \mathrm{~cm}$ deep with a tractor mounted vacuum drill ( $47 \mathrm{~mm}$ outside dia.). Two inoculum bags were installed in each hole, $(10$ and $50 \mathrm{~cm})$ and refilled with compaction using spoil from the same hole, which had been temporarily bagged. Inoculum from 3-4 different flasks were installed within each array of holes at each site.

Non-inoculated plugs were prepared and installed in two arrays at each road site, in a similar way as for P. cinnamomi infested plugs. Tree roots were never intercepted during installation of plugs in the roads. There was no P. cinnamomi recovered from these controls, which were harvested at the time of the final assessment.

\subsubsection{Stockpiles}

At each site, four arrays of holes were arranged linearly over $20 \mathrm{~m}$ on the top of the stockpile with $4 \mathrm{~m}$ buffers between each. They each comprised 20 holes $(5 \times 4)$ with a $50 \mathrm{~cm}$ spacing between holes. Holes for inoculum installation were dug to $50 \mathrm{~cm}$ deep using a powered $65 \mathrm{~mm}$ earth auger (Stihl BT212). Two mesh inoculum bags were installed at 50 and $10 \mathrm{~cm}$, and each hole was refilled with material from the same hole. Within each array, a line of five holes with non-inoculated pine plugs was installed in the same way as colonised plugs. The control plugs were harvested from stockpiles ( 20 per site) at the final harvest. The was no P. cinnamomi recovery from these controls.

\subsubsection{Bunds}

Narrow slits were dug vertically perpendicular to the bund face along $50 \mathrm{~m}$, using a planter spade or square-headed trenching crowbar, depending on the hardness of the ground. Infested pine plugs, in mesh bags, were installed at $30 \mathrm{~cm}$ depth. The installation array was comprised of two parallel lines, with the bottom line $50 \mathrm{~cm}$ above the road pavement and all holes were $80 \mathrm{~cm}$ apart. Holes were closed around the inoculum by compressing the side walls of the hole or slit. The control plugs were harvested from bunds ( 25 per site) at the final harvest. Phytophthora cinnamomi was not recovered from any of these controls.

\subsection{Soil Temperature and Moisture Monitoring}

Data loggers (Measurement Engineering Australia, Margil, South Australia) with two combined temperature/volumetric soil moisture sensors (EnviroPro EP100GL-12, $120 \mathrm{~cm}$, temperature and soil moisture [capacitance type], ex Entelechy P/L, Golden Grove, South Australia), that recorded soil moisture (volumetric, percentage) and temperature $\left({ }^{\circ} \mathrm{C}\right.$ ) were installed at 10, 20, 30, 40, $5060,80,100$ and $120 \mathrm{~cm}$. Readings were taken every $30 \mathrm{~min}$ in stockpiles and roads. At Silky Oak Road, the sensors were installed near the centre of the experimental set-up. The sensors ( $33.5 \mathrm{~mm}$ dia.) were installed in $47 \mathrm{~mm}$ dia. holes and a mixture of 1:1 (w/w) silica sand and bentonite was used to fill the void. At Silky Oak and Redwood stockpiles, the sensors were installed near the center of the experimental set-up using a $100 \mathrm{~mm}$ earth auger and these holes were repacked with screened stockpile soil in addition to a 1:1 silica sand-bentonite mixture. In bunds (Silky Oak, Yellow Tingle, Redwood and Brigalow sites), soil temperatures were monitored at $15 \mathrm{~min}$ intervals at 10 and $30 \mathrm{~cm}$ with TinyTag loggers and sensors (Gemini Data Loggers Ltd., Chichester, UK).

The number of hours per day where soil temperatures were between 32 and 33.99, 34 and 35.99, 36 and $37.99,38$ and 39.99 and $>40{ }^{\circ} \mathrm{C}$ were determined. The cumulative number of hours at these temperature ranges were also presented. 


\subsection{Soil Water Matric Potential}

At Silky Oak Road, soil water characteristics were to be determined in mid-December 2016, by comparing point values of volumetric water content with the matric potential determined from samples taken at the same time and depth. Soil samples were recovered from $5 \mathrm{~cm}$ either side of the placement of probes at 10,20,30, 40 and $50 \mathrm{~cm}$ depths. Samples were immediately sealed in plastic bags. The matric potential of samples was estimated using the filter paper method [32,33], using $200 \mathrm{~mL}$ of each soil sample (sieved to $\leq 2 \mathrm{~mm}$ ) that was repacked to a similar density as in the field. Matric potential values used are means of 2-3 samples from the same soil depth, site, time, and location, within $5 \mathrm{~m}$ of a sensor array. Volumetric soil moisture values are the mean of two sensor readings at the same depth, time and site. This method is considered satisfactory for the measurement of matric potential in the range of $-1.0 \mathrm{~m}$ to $-1000 \mathrm{~m}(-1 \mathrm{kPa}$ to $-10 \mathrm{MPa})$.

\subsection{Recovery of Phytophthora Cinnamomi}

Harvests to recover plugs to determine viability of inoculum at each depth occurred up to 38 months after installation. The road sites (Silky Oak, Yellow Tingle, Redwood and Brigalow) were harvested at 6, 12, 15 and 21 months with 56 plugs collected per site (244 plugs each harvest). The stockpile sites (Silky Oak, Yellow Tingle, Redwood and Acacia) were harvested at 6, 14, 20 and 36 months with 40 plugs collected per site (160 plugs each harvest). The McCoy bunds sites (Silky Oak, Yellow Tingle, Redwood and Brigalow) were harvested at 8, 12, 22 and 38 months, while the Myara sites (Manning, Myara Track, North Road and Ingpen) were harvested at 5, 9, 13 and 25 months. At each bund site, 25 plugs were collected at each harvest (200 plugs from bunds per harvest).

To recover the inoculum, holes were drilled close to placement depth with a powered earth auger (Stihl BT121) with a $40 \mathrm{~mm}$ dia. auger, the hole cleared, and inoculum bags recovered using a Jarrett style hand auger (42 $\mathrm{mm}$ dia.). Recovered inoculum plugs were placed individually in small ziplock plastic bags and stored in a polystyrene box on ice $\left(25-30^{\circ} \mathrm{C}\right)$ for transport to the laboratory. In the laboratory, they were stored at room temperature $\left(22-24{ }^{\circ} \mathrm{C}\right)$ for one to three days before being processed.

In the laboratory, inoculum plugs had soil brushed off prior to being split longitudinally into at least four pieces. Each piece was cut transversely, followed by two tangential cuts resulting in four segments per plug. The plug segments were placed, cut surfaces down, on NARPH and incubated at room temperature in the dark. Plates were examined for growth of P. cinnamomi from between two and ten days. Where P. cinnamomi was not recovered from a plug, segments from the sample were leached in deionised water for 5-7 days, blotted dry and re-plated onto NARPH, to increase the likelihood of breaking dormancy.

\subsection{Statistical Analysis}

Recovery of $P$. cinnamomi from stockpiles was examined using a repeated-measures ANOVA with the repeated measures factors of depth and time. The Greenhouse-Geisser (G-G) epsilon was used to correct the DF and $\mathrm{p}$ for the main effects and interactions involving the repeated measures factor. The G-G epsilon was 0.56 .

Recovery of P. cinnamomi from McCoy and Myara bunds was also examined, separately, using a repeated measure ANOVA (time). The G-G epsilon was used to correct the DF and $p$ for the main effects. The G-G epsilon was 0.49 for McCoy, and 0.053 for Myara location.

\section{Results}

\subsection{Inoculum Recovery}

In total, 75-95\% of plugs were recovered from each site type and assessment. The bags generally remained intact, allowing whole and fragmented plugs to be recovered. Over time it was more difficult 
to recover the deeper bags, as some retrieval lines broke, some bags could not be located, and soft rot destroyed some samples in situ.

\subsubsection{Haul Roads}

Within 12 months, there was no recovery of P. cinnamomi (Figure 2). There was no significant difference in percentage of $P$. cinnamomi recovered from plugs at any time point between the two depths. At 6 months, detection had dropped to $7.5-33 \%$ at $10 \mathrm{~cm}$ and $23-37.5 \%$ at $50 \mathrm{~cm}$. Recovery of P. cinnamomi at 6 months, at $10 \mathrm{~cm}$ and $50 \mathrm{~cm}$, were not significantly different. At 12 and 21 months, there was no recovery at either depth from any of the sites. At 15 months, there was 3.7\% (1 isolation from 26) detected at $50 \mathrm{~cm}$ deep in Silky Oak Road. The larger variation in recovery at $10 \mathrm{~cm}$ is attributed to low $(7.4 \%)$ recovery at Yellow Tingle.

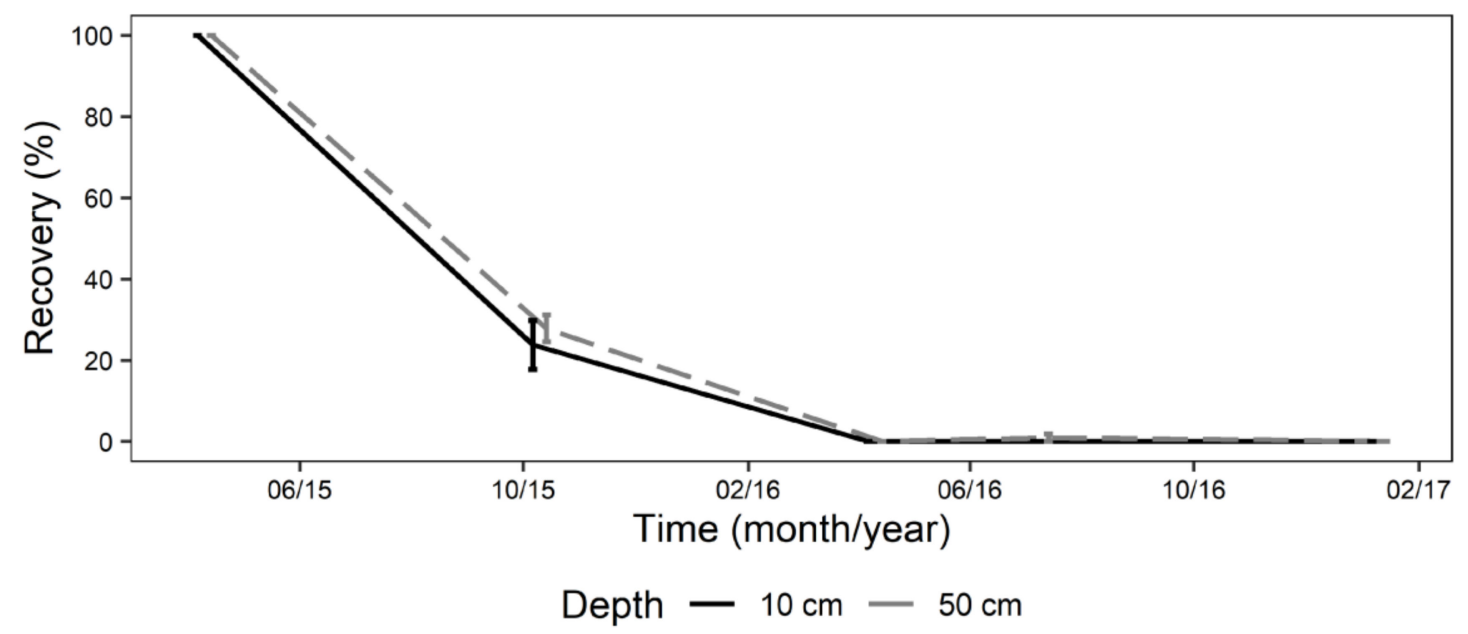

Figure 2. Mean recovery of Phytophthora cinnamomi from four haul roads at the Huntly minesite, recovered from 10 and $50 \mathrm{~cm}$ depth. Error bar = one standard error from the mean.

The reduction of P. cinnamomi recovery by $70 \%$ had occurred within 8 months at Silky Oak road (Figure 3A). Over the first 6 months (winter), the average soil temperatures at $10 \mathrm{~cm}$ were $11^{\circ} \mathrm{C}$ with a range of 4.2 to $24^{\circ} \mathrm{C}$ maximum (Figure 3B). At $50 \mathrm{~cm}$, the temperatures were similar: average $9{ }^{\circ} \mathrm{C}$, minimum 5.4 and maximum $20^{\circ} \mathrm{C}$. During this period, the soil moisture at $10 \mathrm{~cm}$ was $37 \%$ with a minimum of $28.4 \%$ and a maximum of $51 \%$. At this depth, there were 7 days in May 2016 with moisture below $30 \%$, and 8 days in June 2016, of which five were consecutive. At $50 \mathrm{~cm}$, the average soil moisture was $53 \%$ with a minimum of $49 \%$ and a maximum of $68 \%$.

For the second 6 months (October 2015 to May 2016), there were high temperatures and low soil moisture (Figure 3B-D), and during this period, there was no recovery of P. cinnamomi. At $10 \mathrm{~cm}$, there were average soil temperatures of $29^{\circ} \mathrm{C}$, with a range of 14 to $44^{\circ} \mathrm{C}$. The period had $241 \mathrm{~h}$ over 88 days with periods above $32{ }^{\circ} \mathrm{C}, 201 \mathrm{~h}\left(79+\right.$ days) at $34^{\circ} \mathrm{C}, 162 \mathrm{~h}(64+$ days $)$ at $36^{\circ} \mathrm{C}, 112 \mathrm{~h}(41+$ days $)$ at $>38{ }^{\circ} \mathrm{C}$ and $104 \mathrm{~h}\left(25+\right.$ days) at $>40{ }^{\circ} \mathrm{C}$ (Figure 3C). The time when temperatures were $>32{ }^{\circ} \mathrm{C}$ and $<38{ }^{\circ} \mathrm{C}$ coincided with periods when soil moisture dropped below $20 \%$ (Figure $3 \mathrm{C}, \mathrm{D}$ ). The average soil moisture was $30.5 \%$, with a range of $17.5 \%$ to $58 \%$. During December, there were 18 days where moisture was $<20 \%$. At $50 \mathrm{~cm}$, the average temperature of the soil was $24.5^{\circ} \mathrm{C}$, with a minimum of 18 and maximum of $30^{\circ} \mathrm{C}$, moisture was not measured. 

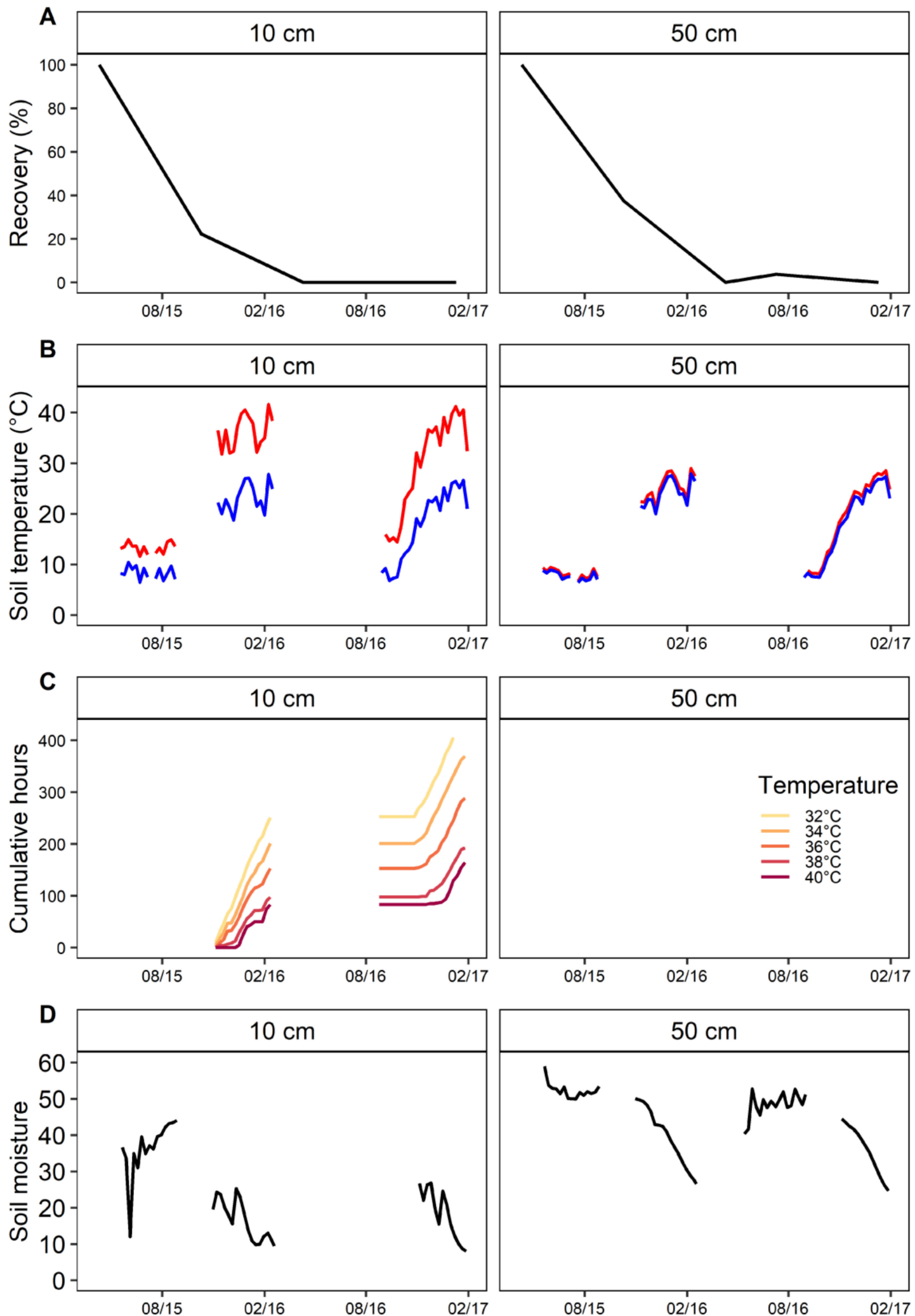

Time (month/year)

Figure 3. (A) Recovery of Phytophthora cinnamomi from Silky Oak Road at 10 and $50 \mathrm{~cm}$ depth in relation to (B) soil temperatures, (C) cumulative number of hours of soil temperatures above $32{ }^{\circ} \mathrm{C}$, and (D) soil moisture (\%). Gaps in temperature and moisture represent missing data. 


\subsubsection{Stockpiles}

The repeated measures ANOVA showed the recovery of P. cinnamomi declined with time in the stockpiles $(p=0.01)$. Phytophthora cinnamomi was eradicated in the stockpiles but only at $10 \mathrm{~cm}$, taking between 12 and 36 months. There were significant $(p=0.05)$ differences in the percentage of P. cinnamomi recovered between the depths of 10 and $50 \mathrm{~cm}$ at all time points (Figure 4). Except for Yellow Tingle, there was no pathogen recovery from 20 months onwards at $10 \mathrm{~cm}$, and $\leq 30 \%$ at $50 \mathrm{~cm}$. Yellow Tingle had a recovery of $83 \%$ at 20 months, dropping to $50 \%$ at 36 months at $50 \mathrm{~cm}$. At $50 \mathrm{~cm}$ only Redwood had $0 \%$ recovery at 36 months.

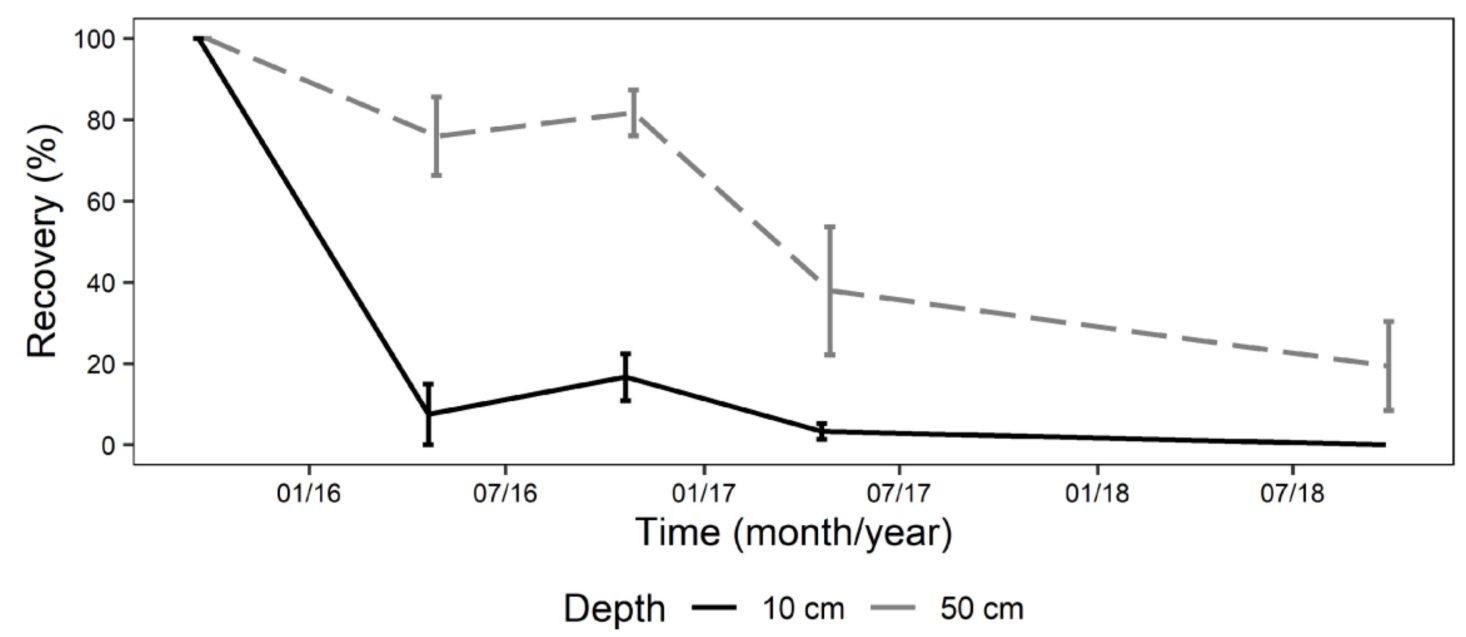

Figure 4. Mean recovery of Phytophthora cinnamomi from four stockpiles in Huntly minesite, at 10 and $50 \mathrm{~cm}$ depth. Error bar = one standard error from the mean.

Although the inoculum plugs at $10 \mathrm{~cm}$ encountered temperatures over $40{ }^{\circ} \mathrm{C}$, in the first 6 months the recovery was $\leq 30 \%$ in 3 of the sites (Figure 4 , Figure $5 \mathrm{~A}, \mathrm{~B}$ and Figure $6 \mathrm{~A}, \mathrm{~B}$ ). The average temperature of the summer of $2015 / 2016$ at $10 \mathrm{~cm}$ was $28^{\circ} \mathrm{C}$ and ranged between 13 and $43{ }^{\circ} \mathrm{C}$. The soil at this depth had 91 days or more with temperatures of $32-34{ }^{\circ} \mathrm{C}$ (cumulative $189 \mathrm{~h}$ ), 85 days with $34-36(154 \mathrm{~h}$ ), 81 days with 36-38 (153 h), 50 days with 38-40 (120 h) and 26 days with temperatures over $40(120 \mathrm{~h})$ (Figure 5C). At $50 \mathrm{~cm}$, the temperature was more regular, the average for the first 6 months was $25^{\circ} \mathrm{C}$, with a minimum of 20 and maximum of $29.5^{\circ} \mathrm{C}$.

The periods of high temperature coincided with low soil moisture (Figure 5B,D and Figure 6B,D). The associated volumetric water content for this period at $10 \mathrm{~cm}$ averaged $17 \%$, with a minimum of $8.5 \%$ and maximum of $29 \%$. At this depth, there were 7 and 27 consecutive days where moisture was below $10 \%$. Of these, 15 consecutive days were below $8 \%$. At $50 \mathrm{~cm}$, the soil moisture averaged $40 \%$ with a minimum $26 \%$ and a maximum of $50.5 \%$.

At 12 months (October 2016), there was no recovery of P. cinnamomi from two of the stockpiles at $10 \mathrm{~cm}$, while at $50 \mathrm{~cm}$, there was an average of $80 \%$ recovery from the four stockpiles (Figure 5). The period from May to October 2016 had average temperatures of $11.2^{\circ} \mathrm{C}$ at $10 \mathrm{~cm}$, with a minimum of 3.2 and a maximum of $31^{\circ} \mathrm{C}$ (Figures $5 \mathrm{~B}$ and $6 \mathrm{~B}$ ). The minimum temperatures occurred overnight from mid-June to the end of August. At $50 \mathrm{~cm}$, the average was $13.1^{\circ} \mathrm{C}, \min 11$ and $\max 18^{\circ} \mathrm{C}$.

The second summer (November 2016 to April 2017) was hotter than the previous summer, with another $110 \mathrm{~h}$ over $38^{\circ} \mathrm{C}$ and $170 \mathrm{~h}$ over $40^{\circ} \mathrm{C}$ at $10 \mathrm{~cm}$ (Figures $5 \mathrm{C}$ and $6 \mathrm{C}$ ). This resulted in $0 \%$ recovery at $10 \mathrm{~cm}$ except for Yellow Tingle, which had a mean recovery of $6.6 \%$ (Figure 4 ). In contrast, there was high variability at $50 \mathrm{~cm}$, with $83 \%$ recovery at Yellow Tingle, and the rest of the sites had on average between 11 and 31\% recoveries. By 36 months (September 2018), there were no recoveries at $10 \mathrm{~cm}$, while at $50 \mathrm{~cm}$ there was $20 \%$ recovery on average for the four sites (Figure 4). 

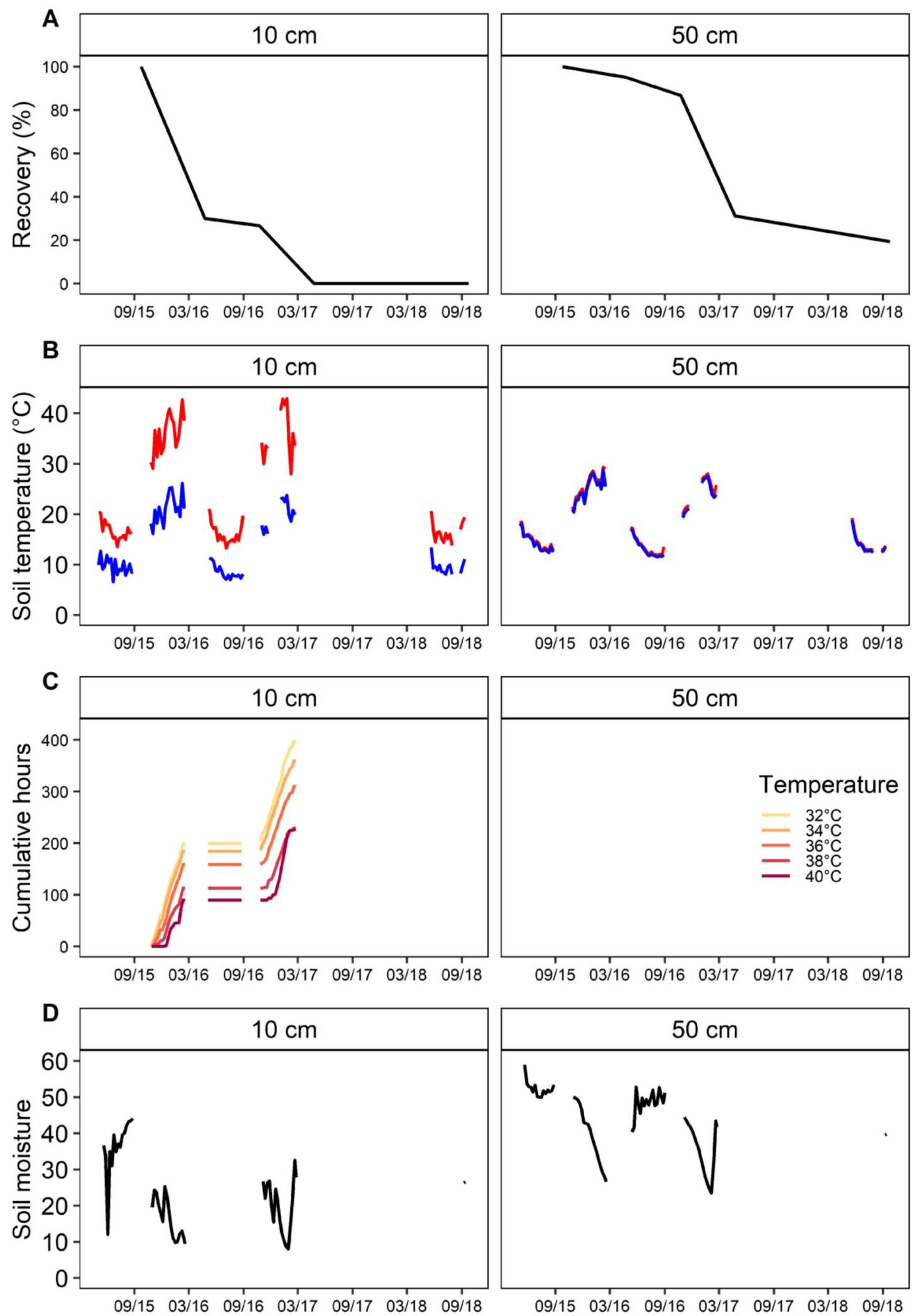

Time (month/year)

Figure 5. (A) Recovery of Phytophthora cinnamomi from Silky Oak stockpile at 10 and $50 \mathrm{~cm}$ depth in relation to (B) soil temperatures, (C) cumulative number of hours of soil temperatures above $32{ }^{\circ} \mathrm{C}$, and (D) soil moisture (\%). Gaps in temperature and moisture represent missing data. 

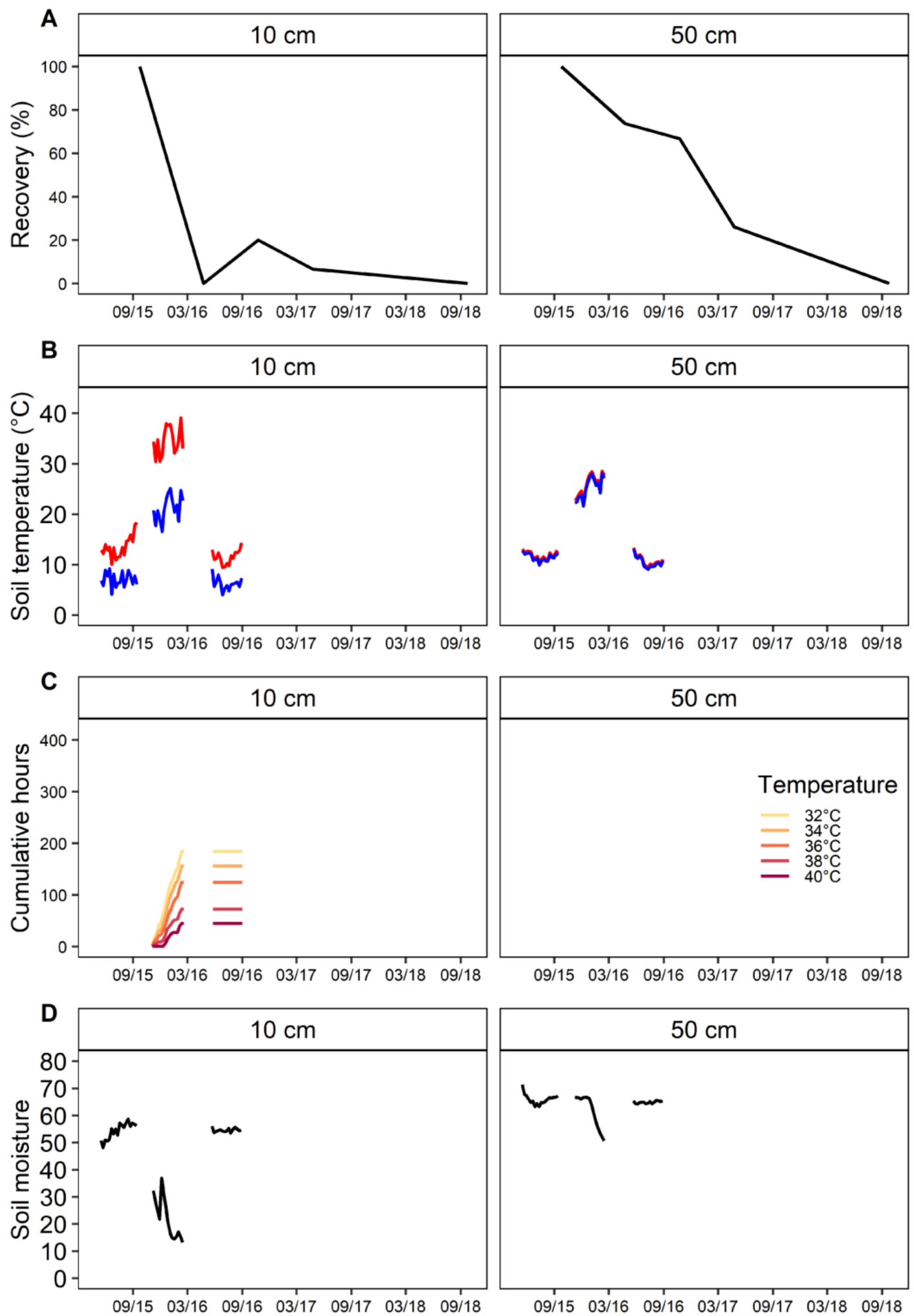

Time (month/year)

Figure 6. (A) Recovery of Phytophthora cinnamomi from Redwood stockpile at 10 and $50 \mathrm{~cm}$ depth in relation to (B) soil temperatures, (C) cumulative number of hours of soil temperatures above $32{ }^{\circ} \mathrm{C}$, and (D) soil moisture (\%). Gaps in temperature and moisture represent missing data.

\subsubsection{Bunds}

For the McCoy bunds, the repeated measures ANOVA showed that recovery of P. cinnamomi declined significantly with time in the stockpiles $(p=0.049)$. The pathogen was quickly killed in the 
Yellow Tingle bund, with only $4 \%$ recovery at 12 months, and no detection at 8,22 or 38 months (Figure 7). This site had similar average, minimum and maximum temperatures to the other sites at this location; 23, 14 and $42{ }^{\circ} \mathrm{C}$ for December 2016 to May 2017, and 12.5, 5 and $22{ }^{\circ} \mathrm{C}$ for May 2017 to October 2017, respectively (Figure 8A). This was one of the smallest bunds in this location (1.4 $\mathrm{m}$ high), with an orientation that gave full exposure to the north and west. The Yellow Tingle bund was comprised mainly of reddish-yellow loamy sand, most likely derived from the mottled and plasmic zones, which occur deeper in the regolith, typically below the lateritic duricrust and above saprolite [30]. This bund had a high number of days (December 2016 to May 2017) with temperatures $>32{ }^{\circ} \mathrm{C}$ (56 days), with a cumulative $57 \mathrm{~h}$, and 19 days with $>34{ }^{\circ} \mathrm{C}$ with 54 cumulative $\mathrm{h}, 5$ days $>36$ $<38{ }^{\circ} \mathrm{C}$ with $15 \mathrm{~h}$ total (Figure $8 \mathrm{~B}$ ).

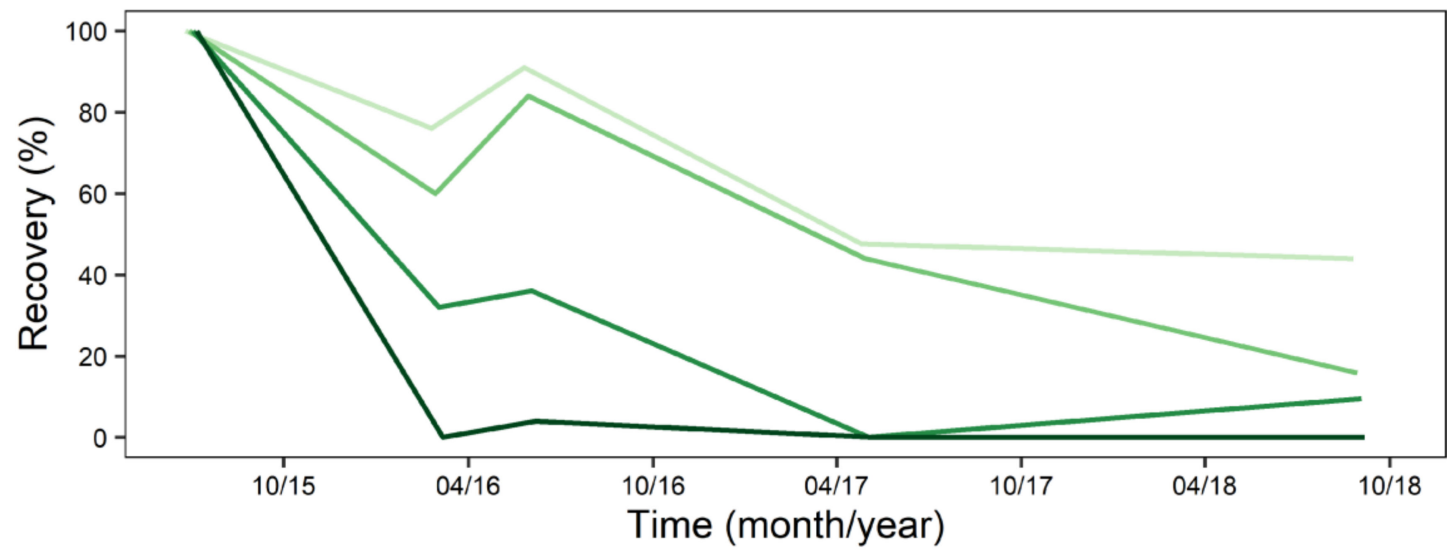

$$
\text { Location - Redwood - Brigalow - Silky Oak — Yellow Tingle }
$$

Figure 7. Mean recovery of Phytophthora cinnamomi from four bunds in the McCoy location in Huntly minesite at $30 \mathrm{~cm}$ depth.

Inoculum recovery in the Silky Oak bund was 32-36\% at 8 and 12 months, with $10 \%$ recovery at 38 months (September 2018) (Figure 7). This site had an average of $24.4{ }^{\circ} \mathrm{C}$, minimum of $16{ }^{\circ} \mathrm{C}$ and maximum of $41.4^{\circ} \mathrm{C}$ (December 2016-May 2017) (Figure 8A), and at 22 months, there was $0 \%$ recovery. This was after a period of 37 days that had $>32{ }^{\circ} \mathrm{C}$ with 130 cumulative $\mathrm{h}$, and 16 days with $>34^{\circ} \mathrm{C}$ (52 h total) and 2 days $(5 \mathrm{~h})>36^{\circ} \mathrm{C}$ (Figure 8B). From May 2017 to October 2017, there was an average of 14 , minimum of 17 and maximum $24^{\circ} \mathrm{C}$. The lowest temperatures experienced were observed for 7 nights in July 2017 with periods $<10^{\circ} \mathrm{C}$ of which 4 also had $<8{ }^{\circ} \mathrm{C}$ (Figure $8 \mathrm{~B}$ ). In August 2017, there were 8 nights with temperatures of $<10^{\circ} \mathrm{C}$, which included periods $<8^{\circ} \mathrm{C}$. During September 2017, there were 4 mornings with $<10^{\circ} \mathrm{C}$. This bund also contained yellow sand in the top layers. However, at the end of this period, P. cinnamomi was recovered from $10 \%$ of the plugs (Figure 7).

The Brigalow bund was less affected by the temperature extremes than Yellow Tingle and Silky Oak bund. It was the largest of the bunds in this location, at $1.75 \mathrm{~m}$ high, with the top layers comprised of red and yellow sands. At 12 months, P. cinnamomi was recovered from $84 \%$ of the plugs (Figure 7), even though this bund had the highest cumulative hours at high temperatures (Figure $8 \mathrm{~F}$ ). Then, from December 2016 to April 2017, the average temperature was $26^{\circ} \mathrm{C}$, with a minimum of $16^{\circ} \mathrm{C}$ and maximum of $40{ }^{\circ} \mathrm{C}$ (Figure $8 \mathrm{E}$ ). The number of days $>32^{\circ} \mathrm{C}$ was $63(201 \mathrm{~h}), 35$ days with $>34^{\circ} \mathrm{C}$ $\left(119 \mathrm{~h}\right.$ ) and 11 days with $34 \mathrm{~h}>36^{\circ} \mathrm{C}$ (Figure $8 \mathrm{~F}$ ). However, there was still $44 \%$ recovery after this (Figure 7). From May 2017 to September 2018, the Brigalow bund encountered an average of $15^{\circ} \mathrm{C}$ with minimum of $9{ }^{\circ} \mathrm{C}$ and maximum of $26^{\circ} \mathrm{C}$ with periods under $10{ }^{\circ} \mathrm{C}$ : Four nights at end of June 2017 and 10 and 6 nights in July and August 2017, respectively. There were 4 and 3 nights that had part of the night at $<8{ }^{\circ} \mathrm{C}$ in July and August 2017, respectively (Figure $8 \mathrm{~F}$ ). The final P. cinnamomi recovery was $16 \%$. 

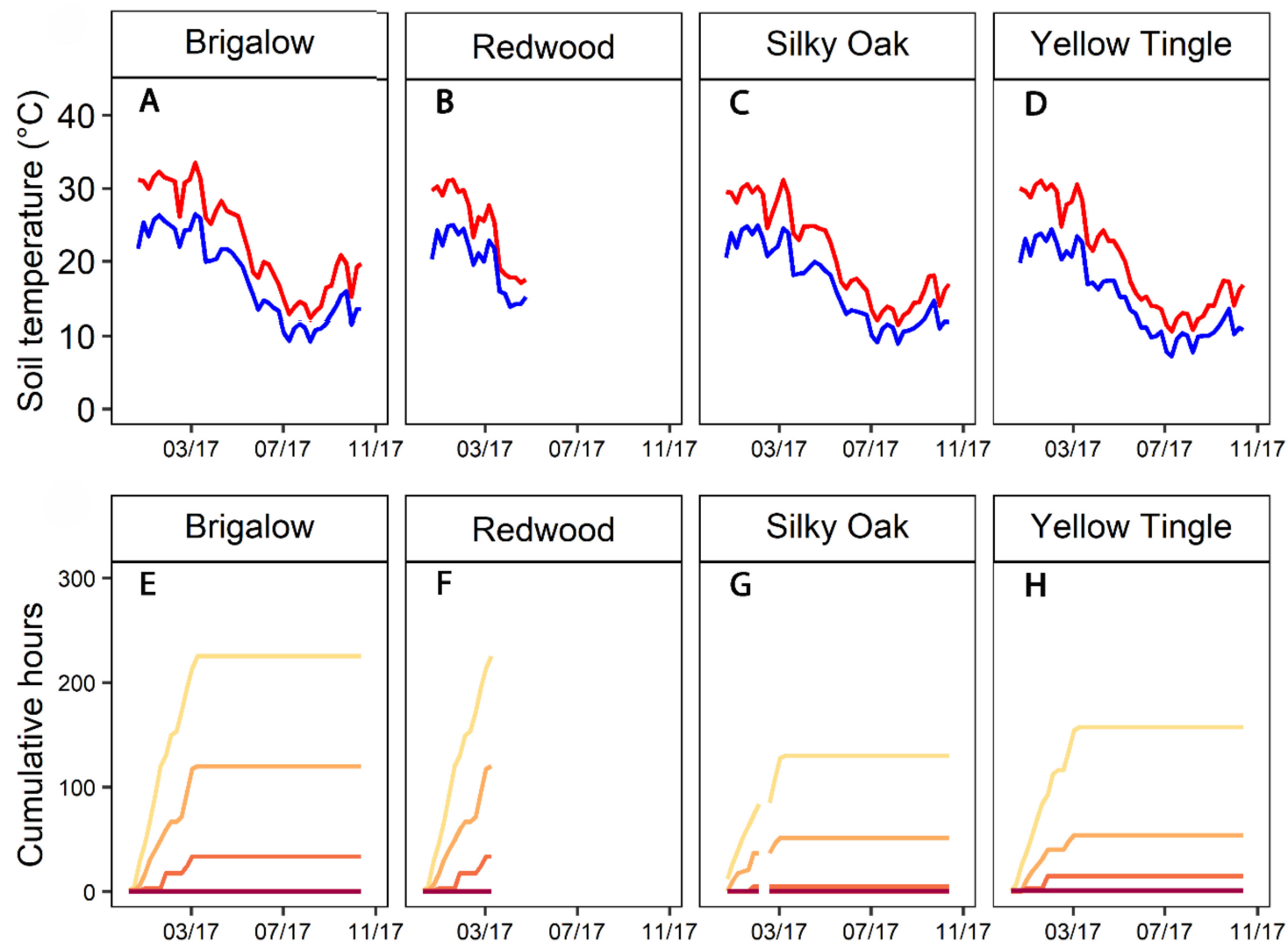

Time (month/year)

Figure 8. Soil temperatures at $30 \mathrm{~cm}$ depth of (A) Yellow Tingle bund (B) Silky Oak bund (C) Brigalow bund and (D) Redwood bund, and the cumulative number of hours of soil temperatures $>32{ }^{\circ} \mathrm{C}$ at $(\mathbf{E})$ Yellow Tingle bund (F) Silky Oak bund (G) Brigalow bund and (H) Redwood bund.

The shaded, small (1.4 $\mathrm{m}$ high) Redwood bund had the greatest recovery of P. cinnamomi at all time periods in this area, with $91 \%$ recovery at 12 months (June 2016) dropping to $44 \%$ recovery at 3 years (September 18; Figure 7). The summer temperatures (December 2016 to April 2017) reduced recovery to $48 \%$, with an average temperature of $22.2{ }^{\circ} \mathrm{C}$, and a minimum of $12{ }^{\circ} \mathrm{C}$ and maximum of $37^{\circ} \mathrm{C}$ (Figure $8 \mathrm{H}$ ). This was $3-4{ }^{\circ} \mathrm{C}$ lower than the other sites in this area, and the number of days and cumulative hours of high temperatures were also lower; 23 days with 76 cumulative $\mathrm{h}>32{ }^{\circ} \mathrm{C}, 9$ days $(28 \mathrm{~h})>34{ }^{\circ} \mathrm{C}$, and 2 days $(2 \mathrm{~h})>36{ }^{\circ} \mathrm{C}$ (Figure $8 \mathrm{~B}$ ).

For the Myara bunds, the repeated measures ANOVA showed that recovery of P. cinnamomi declined with time in the stockpiles $(p=0.0003)$. The Myara Track bund was the highest $(1.75 \mathrm{~m})$ in this location and the only one to have continuous sun exposure and a mix of red and yellow sands. In this area, this bund had the greatest reduction in P. cinnamomi recovery at 5 and 10 months with $\leq$ half of the other sites (Figure 9). After the second summer, the recovery of P. cinnamomi from the inoculum plugs was $4 \%$. This was matched by the North Road site, which although lower (1.2 $\mathrm{m}$ high), also had a mix of yellow and red sands at the surface and had seasonal shading.

The Ingpen bund had the lowest reduction in recovery from the inoculum plugs (Figure 9). This site was shaded for part of the day and was comprised of a red loamy sand as the fine soil. After the first summer (April 2016), the recovery was 75\% and after the second summer (May 2017), this had only reduced to $63 \%$. 


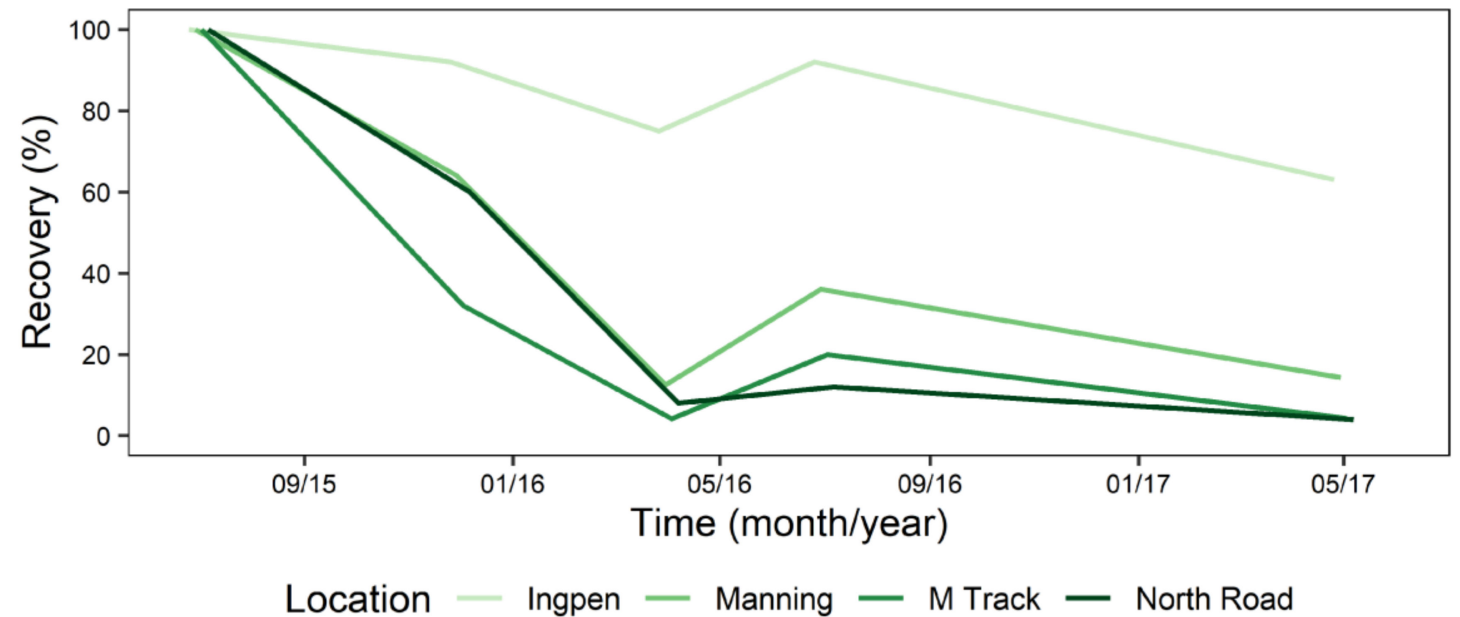

Figure 9. Mean recovery of Phytophthora cinnamomi from four bunds in the Myara location in Huntly minesite at $30 \mathrm{~cm}$ depth.

\subsection{Fallow and Seedling Recruitment}

At no time did plants recruit on the haul roads. Whilst on the bunds plant recruits were rare, and only occurred in the first 12 months. In contrast, on the top-soil stockpiles recruits did occur in autumn-spring (period of rainfall) for the duration of the experiment. There were no recoveries of the pathogen at $10 \mathrm{~cm}$, where inoculum plugs were potentially in closest contact with recruit seedlings.

\subsection{Matric Potential}

There was a very poor relationship between soil volumetric water content values and matric potentials, which precluded production of a soil water characteristic typical for soil of similar texture (loamy sand), constructed by other researchers [32,33]. The most likely cause of this was heterogeneity in particle size distribution in the soil, where homogeneity is an essential assumption for construction of a soil water characteristic [33]. While the samples used to determine matric potential were relatively homogeneous, the profiles where the soil temperature and moisture sensors were installed were unlikely to be homogeneous below $20 \mathrm{~cm}$. While volumetric data could not be converted to matric potentials, some time point estimates for soil water matric potential were determined. In mid-December 2016, mean soil water matric potential ranged from $-3.1 \mathrm{MPa}$ to $-8.5 \mathrm{MPa}$ between 50 and $20 \mathrm{~cm}$, and was very much below the effective range of the method at some sampled times (lower limit, $-10 \mathrm{MPa})$ [33].

\section{Discussion}

This study provides strong support for using a fallow period to reduce or eliminate P. cinnamomi inoculum, particularly in a Mediterranean climate where high soil temperatures occur at periods of low soil moisture. The compaction and composition of the haul roads, roadside bunds and topsoil stockpiles, along with shading influenced the survival of the pathogen. When soil temperatures exceeded $34^{\circ} \mathrm{C}$ for extended periods, the recovery of the pathogen decreased rapidly.

Temperatures considered "fatal" to P. cinnamomi did not occur at road sites at $50 \mathrm{~cm}$ deep, instead the fallow effect has rendered the plugs of inoculum non-viable after one summer. The maximum temperatures at $50 \mathrm{~cm}$ (and $100 \mathrm{~cm}$ ) deep were close to the minimum temperatures recorded at $10 \mathrm{~cm}$ at the same time, and thus unlikely to be the contributing factor of the demise of the inoculum. The moisture content at $50 \mathrm{~cm}$ appeared to be consistently higher than $10 \mathrm{~cm}$. The nature of the construction/compaction of the road material may also contribute to the low survival of P. cinnamomi. In contrast, there was a significant difference in pathogen recovery in the stockpiles between the depths 
of 10 and $50 \mathrm{~cm}$, more reflective of the differences in temperatures between depths. This may indicate that speed of elimination of the pathogen is strongly influenced by high temperatures. At $50 \mathrm{~cm}$ deep where pathogen recovery from stockpiles was significantly higher than at $10 \mathrm{~cm}$, the fallow effect has not been a strong influence, although recoveries were continuing to decline over time. In the smaller structures, the bunds, there was a greater effect of soil type and daily and seasonal shading, which reduced soil temperatures.

In the 1970s, it was noted that introduced P. cinnamomi populations decreased over time in natural environments [34], which they later attributed to a decrease of living host roots; therefore, a loss of suitable ecological habitat and/or an increase in antagonists [35]. Collins et al. [36] concluded that P. cinnamomi has low levels of dormancy and saprotrophic ability as its recovery from individual diseased B. grandis in natural soil declined from $60 \%$ of samples at 3 months to $0.1 \%$ at 34 months post tree death. At a depth of $10 \mathrm{~cm}$, the decline of pathogen survival in the current study was more rapid than that reported by Collins et al. [36] and the pathogen was non-detectable in a shorter period; however, our inoculum material was smaller, and our non-natural sites lacked the attributes of a rhizosphere. It is difficult to make direct comparison as these two studies were run at different times of the year and in different soil types. Collins et al. [36] experiment was in natural forest, which experienced lower maximum temperatures, lower minimums (winter) and lower soil moisture during summer. The most likely explanation for the results from the current study align with Jung et al. [37] who demonstrated that P. cinnamomi is isolated from root fragments not free propagules in the soil. They found that during dry summer periods root tissue containing "selfed oospores, hyphal aggregations, and encased hyphae and vesicles" provide long-term survival for P. cinnamomi. Our small inoculum plugs had been colonised by the pathogen prior to installation and were subjected to artificially compacted environments with low amounts of shading, so survival times were relatively short as there was no nearby living host material.

Most experiments on the survival of $P$. cinnamomi at different temperatures have been undertaken in vitro reporting an array of results: above $32^{\circ} \mathrm{C}$ within 16 days $75 \%$ mortality of cultures [38]; grows at $34{ }^{\circ} \mathrm{C}$ [39]; mycelial and chlamydospores die after 'several days' at $36^{\circ} \mathrm{C}$ [40]; mycelium was inactivated after $1-2 \mathrm{~h}$ at $38^{\circ} \mathrm{C}$, and $1-2 \mathrm{~h}$ at $40^{\circ} \mathrm{C}$ was needed to kill all propagules when chlamydospores were present [21]. In vivo experiments demonstrate temperatures that occur near the soil surface are capable of rapidly eliminating $P$. cinnamomi. In moist soil, the pathogen was killed in colonised wheat grains at $41^{\circ} \mathrm{C}$ for $2 \mathrm{~h}$ or $42{ }^{\circ} \mathrm{C}$ for $1 \mathrm{~h}$ [21]. In dry soil, it was only inactivated in wheat grains at $42{ }^{\circ} \mathrm{C}$ after $2 \mathrm{~h}$. The current study had many periods during summer when the temperature exceeded $40^{\circ} \mathrm{C}$ for periods of 3 to $4 \mathrm{~h}$ over consecutive days where temperatures were in excess of $32{ }^{\circ} \mathrm{C}$ for $10 \mathrm{~h}$ or more each day enhancing the chances of eradicating the pathogen.

In the Brisbane Ranges and forests of Wilson's Promontory, soil temperatures from autumn to early summer affected P. cinnamomi populations, while soil moisture in summer and autumn had a significant influence on the population [35]. Drier soil results in lower P. cinnamomi survival [41]. The results of the current experiment reflect this observation, but it cannot be certain whether moisture played a significant part in the outcome as it was relatively high in relation to those reported by other researchers.

Soil temperatures in South-West Western Australia often exceed $30^{\circ} \mathrm{C}$ during summer, with soil moisture potentials below $-6 \mathrm{MPa}$ (-60 bar), while moisture declines to as low as $1 \%[36,42,43]$. While host root material normally protects P. cinnamomi from adverse soil conditions [37], when matric potential dropped below -10 bar $(-1 \mathrm{MPa})$, roots in soil became brittle and P. cinnamomi was not recoverable [44]. The soil matric potential affects the movement of water in soil, and the way soil retains and releases water.

The road construction with a surface layer of gravel allows for the vertical movement/clearance of average/smaller volumes of rainfall within 2 days at this surface level. However, the optimum growth condition in soil for P. cinnamomi is -11 bar $(-1.1 \mathrm{MPa})$, with hyphal growth in soil recorded between $-0.90(-0.09 \mathrm{MPa})$ and -38 bar $(-3.8 \mathrm{MPa})$ [45], demonstrating that two weeks after the heavy 
rain (131 mm on 10/2/2017), the transiently saturated soil profile ( -0.05 to $-5 \mathrm{MPa})$ provided periods of optimal growth and a high probability of pathogen survival. Phytophthora species have different levels of sensitivity to matric potential [45]. In soil, P. cinnamomi sporangium production is inhibited between -2 and -5 bars $(-0.2$ to $-0.5 \mathrm{MPa})$, but within plant material production is inhibited at -0.2 bar ( $-0.02 \mathrm{MPa})$ [45] where poor aeration negatively affects the production of sporangia, and also potentially changes in the competitive soil microbe community. Survival of P. cinnamomi in dry soils was demonstrated between $-0.5(50 \mathrm{kPa})$ and -20 bars $(-2 \mathrm{MPa})$ water potential as chlamydospores were produced [22], although this study was conducted in vitro and in the absence of plants. The survival of Phytophthora spores for 4 to 8 months with little change in viability rates, suggests that microbial degradation is low in conditions up to -30 bars ( $-3 \mathrm{MPa}$ ) [45]. Additionally, oxygen has very low solubility in flooded soils and gets rapidly depleted [46]. These factors may explain the current experiment's findings where there was a decrease in recovery percentage at $50 \mathrm{~cm}$ even though extreme (high) temperatures were not achieved.

The temperature, soil moisture, physical and chemical characteristics of haul roads are most likely to be significantly different from those of natural soils, particularly seasonal temperature and soil moisture regimes, which potentially have direct and indirect positive or negative effects on survival of the pathogen. Thus, it is important to avoid direct extrapolation of the rapid success in the homogenic and compacted nature of roads to the natural environment. In the case of bunds, the presence of yellow sand appeared to be more conducive to eradication, than red sands, rocks or a combination of red and yellow sands. Organic matter content was highest in roads (15.6-16.4\% d.w., fraction $<2 \mathrm{~mm}$ ) and in Redwood and Brigalow bunds (14.7\% and 15.6\%, respectively), in comparison with stockpiles (mean 9.0\%, range 6.1-10.0\%) and other bunds (mean 9.0\%, range 7.1-10.8\%). High organic matter of at least $5 \%$ can suppress disease caused by P. cinnamomi [40] and is attributed to potential predation by other soil organisms [47]. However, these bunds consistently had higher recovery of the pathogen than the other bunds in this location. Redwood (McCoy location) and Ingpen (Myara location) had the highest recovery of P. cinnamomi, and material used in the bund faces included mostly fragmented duricrust and material from the mottled zone, which contained a large proportion of voids. In contrast, at Yellow Tingle site (McCoy location) where recovery of P. cinnamomi declined most rapidly, material used to finish bund faces was relatively fine and apedal, with bund faces well compacted to the depth of their rock cores. Counter-intuitively, pathogen survival was highest at sites where the soil appeared to be driest for the longest. Further research on the materials used to construct bunds is required.

The bunds with high recovery at two and three years had a similar orientation and were small (height), both had some shading. Redwood, a small bund with seasonal partial shading, facing SSW, had $48 \%$ recovery at two years and $44 \%$ at three years. Ingpen bund, had partial shading on a daily basis, was NE facing. In the first summer, the bund experienced temperatures exceeding $34{ }^{\circ} \mathrm{C}$ for $>100 \mathrm{~h}$, yet still had a high recovery. In stockpiles, the recovery of the pathogen at 19 months ranged from 11 to $83 \%$ at $50 \mathrm{~cm}$ deep, which dropped to 0 to $50 \%$ by 36 months. The two stockpiles with the highest recovery at $50 \mathrm{~cm}$ by 19 and 36 months were Silky Oak (31 and 19\%, respectively) and Yellow Tingle (83 and 50\%, respectively). They had largest volume and area of the four stockpiles, and Yellow Tingle stockpile had seasonal afternoon shading. The Silky Oak stockpile did not exceed $32{ }^{\circ} \mathrm{C}$ at $50 \mathrm{~cm}$. In the field, the bunds and stockpiles were subject to large temperature and moisture fluctuations between winter and summer, with temperature minimums and maximums that have previously been reported to be fatal. However, in the field, the heterogenic nature of the soils and compaction of these structures means that pockets of the structures remain conducive to survival of the pathogen in the absence of living hosts. To overcome these issues, several approaches can be taken in minesites, and other places where there are spot infections. In addition to keeping the soils free of any living plants including germinants, where possible, the orientation of stockpiles should be considered to intensify the temperature of the structures. The stockpiles should be constructed where shading is minimised. The size of stockpiles should be reduced to allow for greater heating of the soils. 


\section{Conclusions}

We have demonstrated that combining a fallow approach together with exposure to high summer soil temperatures caused a rapid reduction in the percentage recovery of $P$. cinnamomi in haul roads where the pathogen was eradicated within 12 months. Declines in recovery from bunds and stockpiles were also observed but not as rapidly or to the same degree as haul roads. Further studies are required to improve our understanding of the fallow process in bunds and stockpiles to ensure effective eradication.

Based on our findings, we recommend fallow periods of 36 months for haul roads as an effective approach to eradicate P. cinnamomi. However, it is important to keep the sites being treated free of living plant material, even germinants. It is also recommended that after each treatment, the soils should be robustly sampled and baited to confirm the absence of the pathogen. In the case of the stockpiles and bunds, the fallow approach clearly demonstrated significant declines in survival of the pathogen. However, additional studies are needed to determine how the fallow approach can be further modified to ensure eradication within a three-year time frame. The fallow approach has relevance to other soil-borne pathogens (particularly other oomycetes), such as areas with spot infestations. Beyond this, the fallow approach should be utilised in other extractive industries such as gravel and sand mining, and for horticultural spot infections. Strategically, a fallow regime, time and site preparation, can be used for the prevention of the movement of Phytophthora in natural ecosystems to stop the spread into other watersheds.

Supplementary Materials: The following are available online at http://www.mdpi.com/1999-4907/11/10/1101/s1, Table S1: Selected soil characteristics of roads $(0-50 \mathrm{~cm}$ deep), stockpiles $(5-50 \mathrm{~cm})$ and bunds $(0-30 \mathrm{~cm})$ to test survival of Phytophthora cinnamomi in woody inoculum. plugs. Soil particle size distribution determined by mid infrared analysis (MIR). Soil texture classification according to Marshall (1947) in McDonald et al. (1990), and soil origin after Anand \& Paine (2002) and Anand (2003). Soil colour according to the Munsell colour classification (Anon., 2000), with moist soil. Soil origin: lateritic (L), gravels (G), duricrust (D), and structures: (c) cobbles, fragmental (f), pavement (p). Figure S1: Silky Oak Road monthly average soil temperature $\left({ }^{\circ} \mathrm{C}\right)$ and soil moisture (\%) at depths of 10, 20, 30, 40,50, 60, 80, 100 and $120 \mathrm{~cm}$ between 10/5/15 and 10/9/18, with standard error bars. Two probes were used (black and grey). Where the lines are discontinuous, data are missing. Figure S2: Silky Oak stockpile monthly average soil temperature $\left({ }^{\circ} \mathrm{C}\right)$ and soil moisture $(\%)$ at depths of $10,20,30,40,50$, $60,80,100$ and $120 \mathrm{~cm}$ between 10/5/15 and 10/7/18, with standard error bars. Two probes were used (black and grey). Where the lines are discontinuous, data are missing. Figure S3 Redwood stockpile monthly average soil temperature $\left({ }^{\circ} \mathrm{C}\right)$ and soil moisture $(\%)$ at depths of $10,20,30,40,50,60,80,100$ and $120 \mathrm{~cm}$ between 24/5/15 and $22 / 8 / 16$, with standard error bars. Two probes were used (black and grey). Where the lines are discontinuous, data are missing. Figure S3: Redwood stockpile monthly average soil temperature $\left({ }^{\circ} \mathrm{C}\right)$ and soil moisture $(\%)$ at depths of 10, 20, 30, 40, 50, 60, 80, 100 and $120 \mathrm{~cm}$ between 24/5/15 and 22/8/16, with standard error bars. Two probes were used (black and grey). Where the lines are discontinuous, data are missing.

Author Contributions: Conceptualization, G.E.S.J.H., W.A.D. and T.I.B.; methodology, G.E.S.J.H., W.A.D. and T.I.B.; validation, K.H. and C.S. formal analysis, K.H. and C.S.; investigation, W.A.D.; resources, G.E.S.J.H., W.A.D., A.G. and T.I.B.; data curation, W.A.D. and K.H.; writing-original draft preparation, K.H. and W.A.D.; writing-review and editing, G.E.S.J.H., A.G. and T.I.B.; supervision, G.E.S.J.H. and T.I.B.; project administration, T.I.B.; funding acquisition, G.E.S.J.H., A.G. and T.I.B. All authors have read and agreed to the published version of the manuscript.

Funding: This research was funded by the Australian Research Council, grant number LP130100573 `Eradication of Phytophthora cinnamomi from infested haul roads and rehabilitated bauxite mine sites in the Eucalyptus marginata forest'.

Acknowledgments: We thank Vicki Stokes and Sarah Way (formerly Alcoa of Australia) for assistance in operational planning and the establishment of experimental sites. We acknowledge technical support from Jamba Gyeltshen, Briony Williams and Rajah Belhaj. Michal Calver assisted with the statistical analysis.

Conflicts of Interest: The authors declare no conflict of interest.

\section{References}

1. Lowe, S.; Browne, M.; Boudjelas, S.; De Poorter, M. 100 of the World's Worst Invasive Alien Species-A Selection from the Global Invasive Species Database; Invasive Species Specialist Group (ISSG): Auckland, New Zealand, 2000; p. 12. 
2. Burgess, T.I.; Scott, J.K.; McDougall, K.L.; Stukely, M.J.C.; Crane, C.; Dunstan, W.A.; Brigg, F.; Andjic, V.; White, D.; Rudman, T.; et al. Current and projected global distribution of Phytophthora cinnamomi, one of the world's worst plant pathogens. Glob. Chang. Biol. 2017, 23, 1661-1674. [CrossRef]

3. Richardson, D.M.; Pysek, P.; Rejmanek, M.; Barbour, M.G.; Panetta, F.D.; West, C.J. Naturalization and invasion of alien plants: Concepts and definitions. Divers. Distrib. 2000, 6, 93-107. [CrossRef]

4. Cahill, D.M.; Rookes, J.E.; Wilson, B.A.; Gibson, L.; McDougall, K.L. Phytophthora cinnamomi and Australia's biodiversity: Impacts, predictions and progress towards control. Aust. J. Bot. 2008, 56, 279-310. [CrossRef]

5. Scott, P.; Bader, M.; Burgess, T.I.; Hardy, G.E.S.J.; Williams, N. Global biogeography and invasion risk of the plant destroyer genus Phytophthora. Environ. Sci. Policy 2019, 101, 175-182. [CrossRef]

6. Colquhoun, I.J.; Hardy, G.E. Managing the risks of Phytophthora root and collar rot during bauxite mining in the Eucalyptus marginata (Jarrah) forest of Western Australia. Plant Dis. 2000, 84, 116-127. [CrossRef] [PubMed]

7. Myers, N.; Mittermeier, R.A.; Mittermeier, C.G.; da Fonseca, G.A.B.; Kent, J. Biodiversity hotspots for conservation priorities. Nature 2000, 403, 853-858. [CrossRef]

8. Colquhoun, I.J.; Kerp, N.L. Minimizing the spread of a soil borne plant pathogen during a large scale mining operation. Restor. Ecol. 2007, 15, S85-S93. [CrossRef]

9. Grant, M.; Koch, J. Decommissioning Western Australia's first bauxite mine: Co-evolving vegetation restoration techniques and targets. Ecol. Restor. Man. 2007, 8, 92-105. [CrossRef]

10. Shearer, B.L.; Crane, C.E.; Cochrane, A. Quantification of the susceptibility of the native flora of the south-west Botanical Province, Western Australia, to Phytophthora cinnamomi. Aust. J Bot. 2004, 52, 435-443. [CrossRef]

11. Hardy, G.E.; Barrett, S.; Shearer, B.L. The future of phosphite as a fungicide to control the soilborne plant pathogen Phytophthora cinnamomi in natural ecosystems. Aust. Plant Pathol. 2001, 30, 133-139. [CrossRef]

12. Wilkinson, C.J.; Holmes, J.M.; Tynan, K.M.; Colquhoun, I.J.; McComb, J.A.; Hardy, G.E.S.J.; Dell, B. Ability of phosphite applied in a glasshouse trial to control Phytophthora cinnamomi in five plant species native to Western Australia. Australas. Plant Pathol. 2001, 30, 343-351. [CrossRef]

13. Dunstan, W.A.; Rudman, T.; Shearer, B.L.; Moore, N.A.; Paap, T.; Calver, M.C.; Dell, B.; Hardy, G.E.S.J. Containment and spot eradication of a highly destructive, invasive pathogen (Phytophthora cinnamomi) in natural ecosystems. Biol. Invasion 2010, 12, 913-925. [CrossRef]

14. Dunne, C.P.; Crane, C.E.; Biddulph, D.; Lee, M.; Young, G.; Massenbauer, T.; Barrett, S.; Comer, S.; Freebury, G.J.C.; Utber, D.J.; et al. A review of the catchment approach techniques used to manage Phytophthora cinnamomi infestation of native plant communities of the Fitzgerald River National Park on the south coast of Western Australia. New Zealand J. For. Sci. 2011, 41, S121-S132.

15. McCarren, K.L.; McComb, J.A.; Shearer, B.L.; Hardy, G.E. The role of chlamydospores of Phytophthora cinnamomi-A review. Aust. Plant Path. 2005, 34, 333-338. [CrossRef]

16. Crone, M.; McComb, J.A.; O'Brien, P.A.; Hardy, G.E. Host removal as a potential control method for Phytophthora cinnamomi on severely impacted black gravel sites in the jarrah forest. Pathology 2014, 44, 154-159. [CrossRef]

17. Smith, G.R.; Fletcher, J.D.; Marroni, V.; Kean, J.M.; Stringer, L.D.; Vereijssen, J. Plant pathogen eradication: Determinants of successful programs. Australas. Plant Pathol. 2017, 46, 277-284. [CrossRef]

18. Sena, K.L.; Yeager, K.M.; Dreaden, T.J.; Barton, C.D. Phytophthora cinnamomi colonized reclaimed surface mined sites in Eastern Kentucky: Implications for the restoration of susceptible species. Forests 2018, 9, 203. [CrossRef]

19. Burgess, T.I.; White, D.; McDougall, K.M.; Garnas, J.; Dunstan, W.A.; Català, S.; Carnegie, A.J.; Worboys, S.; Cahill, D.; Vettraino, A.-M.; et al. Distribution and diversity of Phytophthora across Australia. Pac. Cons. Biol. 2017, 23, 150-162. [CrossRef]

20. Crone, M.; McComb, J.A.; O’Brien, P.A.; Hardy, G.E.S.J. Survival of Phytophthora cinnamomi as oospores, stromata, and thick-walled chlamydospores in roots of symptomatic and asymptomatic annual and herbaceous perennial plant species. Fungal Biol. 2013, 117, 112-123. [CrossRef]

21. Gallo, L.; Siverio, F.; Rodriguez-Perez, A.-M. Thermal sensitivity of Phytophthora cinnamomi and long-term effectiveness of soil solarisation to control avocado root rot. Annals Appl. Biol 2007, 150, 65-73. [CrossRef]

22. Weste, G.; Vithanage, K. Survival of chlamydospores of Phytophthora cinnamomi in several non-sterile host-free forest soils and gravels at different soil water potentials. Aust. J. Bot. 1979, 27, 1-9. [CrossRef] 
23. Gyeltshen, J.; Dunstan, W.A.; Grigg, A.H.; Burgess, T.I.; Hardy, G.E. The influence of time, soil moisture, and exogenous factors on the survival potential of oospores and chlamydospores of Phytophthora cinnamomi. For. Pathol. 2020. [CrossRef]

24. Anand, R.R. Jarrahdale District, Western Australia. In Regolith Landscape Evolution Across Australia: A Compilation of Regolith-Landscape Case Studies and Landscape Evolution Models; Anand, R.R., de Broekert, P., Eds.; Cooperative Research Centre for Landscapes Environments and Mineral Exploration: Millaa Millaa, QLD, Australia, 2003; Available online: http://crcleme.org.au/Pubs/Monographs/RegLandEvol.html (accessed on 13 April 2020).

25. Tibbett, M. Mining in Ecologically Sensitive Landscapes: Concepts and Challenges. In Mining in Ecologically Sensitive Landscapes; Tibbett, M., Ed.; CSIRO Publishing: Clayton, VIC, Australia, 2015; pp. 3-6.

26. Shearer, B.L.; Tippett, J.T. Jarrah Dieback: The Dynamics and Management of Phytophthora cinnamomi in the Jarrah (Eucalyptus marginata) Forest of South-Western Australia; Department of Conservation and Land Management, Western Australia Research Bulletin; Department of Conservation and Land Management: Bently, Australia, 1989; Volume 3, p. 76.

27. Munsell, A.H. Munsell Soil Color Charts: Year 2000 Revised Washable Edition; New Windsor: Brightwaters, NY, USA, 2000.

28. Marshall, T.J. Mechanical Composition of Soil in Relation to Field Descriptions of Texture; 1947; Australia Bulletin 224; CSIRO Publishing: Clayton, VIC, Australia.

29. McDonald, R.C.; Isbell, R.F.; Speight, J.G.; Walker, J.; Hopkins, M.S. Australian Soil and Land Survey Field Handbook, 2nd ed.; Inkata Press: Melbourne, Australia, 1990.

30. Anand, R.R.; Paine, M. Regolith geology of the Yilgarn Craton, Western Australia: Implications for exploration. Aust. J. Earth Sci. 2002, 49, 3-162. [CrossRef]

31. Sarker, S.R.; McComb, J.A.; Burgess, T.I.; Hardy, G.E.S. Antimicrobials in Phytophthora isolation media and the growth of Phytophthora species. Plant Pathol. 2020. [CrossRef]

32. Greacen, E.L.; Walker, G.R.; Cook, P.G. Procedure for the Filter Paper Method of Measuring Soil Water Suction; CSIRO Divisional Report, No. 108; CSIRO Publishing: Clayton, VIC, Australia, 1989.

33. Cresswell, H.P. The Soil Water Characteristic. In Soil Physical Measurement and Interpretation for Land Evaluation; Australian Soil and Land Survey Handbook Series; McKenzie, N., Coughlan, K., Cresswell, H., Eds.; CSIRO Publishing: Collingwood, VIC, Australia, 2002; Volume 5, pp. 59-84.

34. Weste, G.; Cooke, D.; Taylor, P. The invasion of native forest by Phytophthora cinnamomi. II. Post-Infection vegetation patterns, regeneration, decline in inoculum and attempted control. Aust. J. Bot. 1973, 21, 13-29. [CrossRef]

35. Weste, G.; Ruppin, P. Factors affecting the population density of Phytophthora cinnamomi in native forests of the Brisbane Ranges, Victoria. Aust. J. Bot. 1977, 23, 77-85. [CrossRef]

36. Collins, S.; McComb, J.A.; Howard, K.; Shearer, B.L.; Colquhoun, I.J.; Hardy, G.E. The long-term survival of Phytophthora cinnamomi in mature Banksia grandis killed by the pathogen. Pathology 2012, 42, 28-36. [CrossRef]

37. Jung, T.; Hardy, G.E.S.J.; Colquhoun, I.J. New insights into the survival strategy of the invasive soilborne pathogen Phytophthora cinnamomi in different natural ecosystems in Western Australia. For. Path. 2013, 43, 266-288. [CrossRef]

38. Hüberli, D.; Tommerup, I.C.; Dobrowlski, M.P.; Calver, M.C.; Hardy, G.E. Phenotypic variation in a clonal lineage of two Phytophthora cinnamomi populations from Western Australia. Mycol. Res. 2001, 105, 1053-1064. [CrossRef]

39. Zentmyer, G.A. Phytophthora cinnamomi and the Diseases It Causes; The American Phytopathological Society: St. Paul, MN, USA, 1980.

40. Nesbitt, H.; Malajczuk, N.; Glenn, A.R. Effect of organic matter on the survival of Phytophthora cinnamomi Rands in soil. Soil Biol. Biochem. 1979, 11, 133-136. [CrossRef]

41. Old, K.; Oros, J.; Malafant, K. Survival of Phytophthora cinnamomi in root fragments in Australian forest soils. Trans. Brit. Mycol. Soc. 1984, 82, 605-613. [CrossRef]

42. Enright, N.J.; Lamont, B.B. Survival, growth and water relations of Banksia seedlings on a sand mine rehabilitation site and adjacent scrub-heath sites. J. Appl. Ecol. 1992, 29, 663-671. [CrossRef]

43. Lamont, B.B.; Bergl, S.M. Water relations, shoot and root architecture, and phenology of three co-occurring Banksia species: No evidence for niche differentiation in the pattern of water use. Oikos 1991, 60, 291-298. [CrossRef] 
44. Mackay, A.; Weste, G.; Sharpe, K. Survival of Phytophthora cinnamomi in buried eucalypt roots. Phytopathol. Z. 1985, 114, 214-223. [CrossRef]

45. Gisi, U. Biophysical Aspects of the Development of Phytophthora. In Phytophthora, Its Biology, Taxonomy, Ecology and Pathology; Erwin, D.C., Bartnicki-Garcia, S., Tsao, P.H., Eds.; APS Press: St. Paul, MN, USA, 1983; pp. 109-120.

46. Duniway, D.M. Role of Physical Factors in the Development of Phytophthora Diseases. In Phytophthora, Its Biology, Taxonomy, Ecology and Pathology; Erwin, D.C., Bartnicki-Garcia, S., Tsao, P.H., Eds.; APS Press: St. Paul, MN, USA, 1983; pp. 175-188.

47. Weste, G.; Marks, G.C. The biology of Phytophthora cinnamomi in Australasian forests. Annu. Rev. Phytopathol. 1987, 25, 207-229. [CrossRef]

Publisher's Note: MDPI stays neutral with regard to jurisdictional claims in published maps and institutional affiliations.

(C) 2020 by the authors. Licensee MDPI, Basel, Switzerland. This article is an open access article distributed under the terms and conditions of the Creative Commons Attribution (CC BY) license (http://creativecommons.org/licenses/by/4.0/). 